DOI: 10.35757/RPN.2011.19.02

Matthias Stickler

\title{
„MY, WYPĘDZENI ZE STRON OJCZYSTYCH, REZYGNUJEMY Z ZEMSTY I ODWETU" - STUTTGARCKA KARTA Z 5-6 SIERPNIA 1950 ROKU JAKO DOKUMENT HISTORYCZNY
}

\begin{abstract}
Najważniejsze fakty
Uchwalona w dniach 5-6 sierpnia 1950 roku w Stuttgarcie Karta niemieckich wypędzonych ${ }^{1}$ należy bez wątpienia do najważniejszych, kluczowych dokumentów niemieckiej historii powojennej także lub właśnie z tego powodu, że po dziś dzień jest różnie interpretowana, a częściowo wręcz ostro krytykowana.

Czołowi politycy Republiki Federalnej, niezależnie od swojej przynależności partyjnej, podkreślali i podkreślają wciąż historyczny wkład Karty do pojednania Niemiec ze wschodnimi sąsiadami. Na przykład Helmut Kohl pisze w swoich wspomnieniach: „Karta z 1950 roku, uchwalona już pięć lat po zakończeniu wojny, z jej uroczystym uzna-

1 Karta niemieckich wypędzonych ze stron ojczystych publikowana była w różnych źródłach, por. np. E. Lemberg et al. (red.): Die Vertriebenen in Westdeutschland. Ihre Eingliederung und ihr Einfluss auf Gesellschaft, Wirtschaft, Politik und Geistesleben, t. 1-3, Kiel 1959, tutaj t. 3, s. 662 i n. Polski przekład Karty ukazał się w wersji niepełnej w: H. Jacobsen, M. Tomala: Warszawa - Bonn 1941-1991. Stosunki polsko-niemieckie. Analiza i dokumenty, Warszawa 1992, s. 48-49. W niniejszym tłumaczeniu wykorzystano, z pewnymi modyfikacjami, tekst Karty dostępny na internetowej stronie Związku Wypędzonych (www.bund_der_vertriebenen.de/derbdv/charta.po.php3) (przyp. red.).
\end{abstract}


niem idei wolnej i zjednoczonej Europy, w której narody mogą żyć bez strachu i przemocy, w swym historycznym znaczeniu nadal nie znajduje należnego jej uznania. Jako pokojowe przesłanie czyni bezpodstawnymi wszelkie zarzuty o rewanżyzm, stawiane organizacjom wypędzonych. To samoograniczenie, rezygnacja z zemsty i odwetu nie była pustą deklaracja lecz jest rzeczywistością. Jest to godne uznania i szacunku, gdyż wciąż jeszcze na świecie znaleźć można przerażające przykłady na to, jak niesprawiedliwość pociąga za sobą chęć i gotowość do odwetu. Wypędzeni w naszym kraju oparli się tej pokusie i zdystansowali się od nielicznych outsiderów, karygodnie igrających z myślą o siłowych zmianach $\mathrm{w}$ Europie" ${ }^{2}$. W podobny sposób wypowiedział się Kohl w 1995 roku w Bundestagu, gdzie stwierdził: „Mówię całkiem otwarcie - nie rozumiem, dlaczego Karty wypędzonych nie podkreśla się częściej jako wzorcowego przykładu kultury politycznej. Była ona i pozostaje nadal dziełem pokoju. Republika Federalna Niemiec, a nawet Europa powinna podziękować wypędzonym za Kartę, którzy po tysiąckroć dotrzymali danej wtenczas obietnicy" ${ }^{\prime \prime}$. Także kanclerz federalna Angela Merkel uczciła Kartę z okazji sześćdziesięciolecia jej podpisania jako dokument pojednania: „Po cierpieniach ucieczki i wypędzenia było bardzo trudno wkroczyć z pełną świadomością na drogę pojednania i porozumienia. Tę drogę do przyszłości wskazała Karta. Państwo, jako Związek Wypędzonych oraz należące do niego ziomkostwa, już od dziesięcioleci nigdy nie zboczyliście z drogi koegzystencji, za co jestem bardzo wdzięczna. Zawsze podążaliście drogą integracji, drogą wspólnej odbudowy naszego kraju" ${ }^{4}$. Także ze strony SPD, która na skutek zmagań o traktaty wschodnie od wczesnych lat siedemdziesiątych XX wie$\mathrm{ku}^{5}$ miała raczej napięte stosunki ze związkami wypędzonych, słychać było raz po raz pozytywne opinie. Na przykład w sierpniu 2000 roku

2 H. Kohl: Erinnerungen 1982-1990, München 2005, s. 371.

3 „Bulletin der Presse- und Informationsamt der Bundesregierung”, nr 45 z 2 czerwca 1995 , s. 393 i nn.

4 Rede von Bundeskanzlerin Merkel beim Jahresempfang des Bundes der Vertriebenen, http://www.bundesregierung.de/Content/DE/Rede/2010/03/2010-03-16-merkel-bundvertriebene.html [5.12.2010]

5 Por. M. Stickler: »Unserer Heimat droht Gefahr!« - Der Kampf des Bundes der Vertriebenen $(B d V)$ gegen die Ostverträge, „Einsichten und Perspektiven. Bayerische Zeitschrift für Politik und Geschichte“ 2010, z. 1, s. 18-33. 
ówczesny federalny minister spraw wewnętrznych Otto Schily podkreślił z okazji pięćdziesięciolecia ogłoszenia Karty jej „dalekosiężne znaczenie", gdyż pozbawiła dążenia niemieckich radykałów ich podstaw, a w polityce zagranicznej utorowała drogę do europejskiego porozumienia z udziałem sąsiadów z Europy Środkowej i Wschodniej ${ }^{6}$. Kanclerz federalny Gerhard Schröder podkreślił 3 września 2000 roku ${ }^{7}$ w przemówieniu podczas „Dnia stron ojczystych” (Tag der Heimat) Związku Wypędzonych wkład organizacji wypędzonych do odbudowy Niemiec i pojednania z sąsiednimi krajami. Wskazał przy tym przede wszystkim na wyrażoną w Karcie rezygnację z zemsty i odwetu oraz na opowiedzenie się za europejską integracją ${ }^{8}$.

Dla Związku Wypędzonych i zrzeszonych w nim organizacji ${ }^{9}$ Karta ma fundamentalne znaczenie przy ich samookreślaniu się ${ }^{10}$. Podczas uroczystości z okazji pięćdziesięciolecia Związku jego przewodnicząca Erika Steinbach stwierdziła: „Prawdziwie wielkim, wspólnym dokonaniem wypędzonych z ojczystych stron był zjazd w Stuttgarcie w 1950 roku, na którym w obecności 100 tys. wypędzonych proklamowano Kartę. W tym skierowanym ku przyszłości manifeście spotkały się różne losy we wspólnym przyrzeczeniu na przyszłość, które brzmiało: Pragniemy przyczyniać się do europejskiego pojednania i przerwać zaklęty krąg zemsty i odwetu. Świadczyło to wymownie o gotowości do wyrzeczeń

6 A. Loesch: Heimatvertriebene. Die Charta der Organisation ist 50 Jahre alt, „Der Tagesspiegel“", 17 sierpnia 2000.

Było to w ogóle pierwsze wystąpienie socjaldemokratycznego kanclerza podczas „Dnia stron ojczystych“, jak też pierwsze przewodniczącego SPD od czasów wystąpień Willy'ego Brandta w latach sześćdziesiątych XX wieku.

8 „Frankfurter Allgemeine Zeitung“, 4 września 2000, s. 5.

9 Na temat niemieckich organizacji wypędzonych por. przede wszystkim M. Stickler: "Ostdeutsch heißt Gesamtdeutsch" - Organisation, Selbstverständnis und heimatpolitische Zielsetzungen der deutschen Vertriebenenverbände 1949-1972, Düsseldorf 2004 oraz przeglądowo idem: Pressure Groups mit gesamtnationalem Anspruch - Organisation, Selbstverständnis und Zielsetzungen der deutschen Vertriebenenverbände, w: Flucht, Vertreibung, Integration, Bielefeld 2005, s. 171-179. Por. także idem: Forschungen zur Geschichte der Vertriebenenverbände - Hinweise auf ein wenig beachtetes Arbeitsfeld der jüngeren Zeitgeschichte, „Historisches Jahrbuch“ 2008, t. 128, s. 469-493. Por. także P. Ahonen: After the Expulsion. West Germany and Eastern Europe 1945-1990, Oxford 2003.

${ }^{10}$ Por. np. H. Czaja: Die Charta als Grundlage einer gesamteuropäischen Friedensordnung, w: BdV (red.): 40 Jahre Charta der deutschen Heimatvertriebenen 1950-1990, Bonn 1990, s. 1 i n. 
i pojednania. Nie było to czymś oczywistym - istniały także inne głosy. Po dziś dzień manifest jest podwaliną wartości wyznawanych przez Związek Wypędzonych. Po upadku muru berlińskiego i przystąpieniu NRD do RFN podstawę tę uznały stowarzyszenia wypędzonych w nowych landach, powstające wtedy zadziwiająco szybko"11. Trzy lata później, z okazji sześćdziesiątej rocznicy uchwalenia Karty, Steinbach podkreślała: „W całościowym ujęciu Karta przyniosła duży zysk. Także wypędzonym. Wiara we własne siły, chęć obrony swoich interesów, a także wola walki o prawne i społeczne zrównanie z mieszkańcami Niemiec, wszystko to wzmocniła ta proklamacja. Dzięki niej mamy ponadczasowy moralny fundament. Mówię to z całym naciskiem i pełna podziwu" ${ }^{\prime 2}$.

Na tle powyższego zadziwiający jest fakt, że Karta ze Stuttgartu była dotychczas raczej po macoszemu traktowana przez badaczy. Analiza jej powstania i historii oddziaływania, spełniająca wszelkie naukowe wymogi i opracowana na podstawie materiałów źródłowych, dotychczas pozostaje tylko życzeniem. Istnieją jedynie opracowania przeglądowe, z których znakomita większość powstała nie tyle w wyniku naukowego, co raczej historyczno-publicystycznego dyskursu. Należy tu wymienić przede wszystkim pisarza Ralpha Giordano (ur. 1923) oraz pedagoga i publicystę Michę Brumlika (ur. 1947) z Frankfurtu. Pierwszy z nich w swojej znanej książce Die zweite Schuld oder Von der Last Deutscher zu sein rozprawił się z Kartą w ostrych słowach. Ma ona być „klasycznym przykładem historycznych sprzeniewierzeń. Przecina jakikolwiek związek przyczynowy pomiędzy przyczyną i skutkiem, ignoruje chronologię wydarzeń, a więc przemilcza genezę wypędzenia, przyczyniając się do wypierania i zaprzeczania pierwotnej winy oraz będąc unikalnym przejawem drugiej winy. [...] »Karta niemieckich wypędzonych ze stron ojczystych « jest przekonującym dokumentem bra$\mathrm{ku}$ emocjonalnego stosunku do świata nazistowskich ofiar, niedającego się pokonać lub ukryć dystansu wobec ich uczuć i historii cierpienia. Jest »drugą stroną", która tu dochodzi do głosu, daleką od antyfaszyzmu i pozbawioną antynazistowskiej wymowy. Jedyny superlatyw, jaki

\footnotetext{
${ }^{11} \mathrm{http}: / /$ www.bund-der-vertriebenen.de/files/rede-festakt-50-jahre-bdv.pdf [5.12.2010].

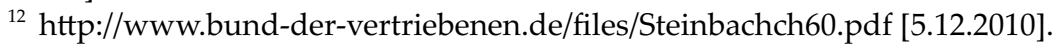


znajdują sygnatariusze tego tekstu pełnego peryfraz i niejasności, służy przywołaniu własnego cierpienia. [...] »Karta niemieckich wypędzonych ze stron ojczystych « tak dokładnie wydrapała w swoim tekście swastykę, że nie pozostał po niej nawet ślad. W ten sposób wszystko stało się niejasne, nieokreślone i wieloznaczne. Ta niejasność daje możliwość wymówki wobec pominiętej lub przemilczanej grupy ofiar: Ależ oczywiście, was też to dotyczy! Karta jest dokumentem świadomej anonimizacji. A przede wszystkim jest dokumentem niemieckiej impertynencji, ponieważ stawia wschodnioeuropejskie narody ofiar na pozycji dłużników, natomiast naród sprawców - na pozycji wierzycieli, dysponujących wspaniałomyślnością i przebaczeniem”. Autor kończy swój wywód słowami: „Stąd to już od dawna spóźnione posłowie, które w obliczu bardzo odległej pierwszej publikacji »Karty« nie miałoby żadnego uzasadnienia, gdyby nie była ona od tamtej pory w swym duchu i słowie źródłem niemieckiego rewizjonizmu i rewanżyzmu. Oprócz jej przemilczeń, niedopowiedzeń i anonimizacji, którymi sama siebie dyskwalifikuje, to przede wszystkim uzurpowana pozycja wierzyciela czyni rzekome pragnienie ugody czymś dwuznacznym, wręcz niewiarygodnym. »Karta« i jej apologeci noszą stygmat drugiej winy - braku gotowości do pokuty"13.

${ }^{13}$ R. Giordano: Die zweite Schuld oder Von der Last Deutscher zu sein, Hamburg 1987, tu cytowane za częściowo poprawionym wydaniem z 1998, s. 267-292, tutaj s. 270, 275, 278 i 292. Giordano reprezentował to stanowisko do około 2003 roku. Jednak po tym, gdy osobiście poznał Erikę Steinbach, zrewidował w pewnym stopniu swój negatywny stosunek do Karty, spowodowany, jak sam argumentuje, także i głównie na skutek masowej i zasadniczej krytyki wobec organizacji wypędzonych i ich polityki. Został członkiem jury nagrody Franza Werfla, ufundowanej przez Centrum przeciwko Wypędzeniom. Podczas wystąpienia na zorganizowanej przez Związek Wypędzonych uroczystości z okazji sześćdziesiątej rocznicy Powstania Warszawskiego (sierpień-październik 1944) bronił Eriki Steinbach i jej projektu Centrum przeciwko Wypędzeniom, por. H.M. Kloth: Giordano bekennt sich zu Steinbachs Politik, "Spiegel Online“, 20 lipca 2004 [http://www.spiegel.de/politik/deutschland/0,1518,309467,00.html, 5.12.2010]; dokumentacja przemówienia w: „Frankfurter Allgemeine Zeitung“, 30 lipca 2004, s. 6. Co prawda Giordano po trzech latach wycofał się z projektu Centrum przeciwko Wypędzeniom, od tego czasu jednak nie zajmował tak krytycznego stanowiska jak wcześniej. Z drugiej strony Erika Steinbach niedawno wyraziła się z wyraźnym uznaniem o krytycznej postawie Giordano, mówiąc, że jest świadoma, iż „w ostatnich latach odzywały się krytyczne głosy na temat Karty. Starannie przemyślałam i wyważyłam zawarte w nich argumenty, o ile nie służyły jedynie polemice. Moim zdaniem nie są one dostatecznie znaczące, gdyż sformułowano je w przeważającym stopniu z dzisiejszej perspektywy. Wyłączam tu Ral- 
Giordano sformułował w 1987 roku najistotniejsze krytyczne argumenty wobec Karty, od tamtej pory wciąż podejmowane przez innych autorów, wśród których wymienić należy szczególnie wspomnianego już Michę Brumlika ${ }^{14}$, który podchwycił krytykę Giordano i częściowo ją wręcz zaostrzy $1^{15}$. Brumlik dowodził, iż Karta stanowi „szowinistyczny akt założycielski godny państwa stanowego, przepojony duchem zemsty (rzekoma rezygnacja z niej świadczy o tym, że jest ona tym bardziej upragniona), współczuciem dla samych siebie i zafałszowywaniem historii, poświadczająca ni mniej ni więcej zamiar wzięcia $\mathrm{w}$ niewolę polityki młodej Republiki Federalnej". Karta jest zdaniem autora „świadectwem, nie, więcej nawet - kwintesencją tego, co można określić jako wypieranie i zakłamywanie”. Według Brumlika Karta jest „długotrwałym politycznym i moralnym skandalem“, gdyż nadal pozostaje w mocy, a jej wymowa zaprzecza nawet najlepszym intencjom planowanego Centrum przeciwko Wypędzeniom ${ }^{16}$. Ostatnia uwaga ukazuje dość wyraźnie, że Brumlik ze swej strony w dużym stopniu instrumentalizuje Kartę w związku z debatą na temat Centrum przeciwko Wypędzeniom, choć w innym miejscu słusznie żąda, by traktować Kartę jako historyczny dokument epoki przejściowej, która minęła ${ }^{17}$. Stylizuje jednak ten dokument na akt założycielski polityki organizacji wypędzonych, skierowanej od początku na rewanżyzm i rewizję historii, która jego zdaniem osiąga obecnie swój nowy punkt kulminacyjny. Argumen-

pha Giordano, z którym czuję się związana przyjaźnią. Jego punkt widzenia ukształtował się pod wpływem osobistych złych doświadczeń ze strony narodowego socjalizmu, któremu ledwo uszedł z życiem. Respektuje jego argumenty, lecz nie podzielam ich" [http://www.bund-der-vertriebenen.de/files/Steinbachch60.pdf, 5.12.2010].

${ }^{14}$ Brumlik urodził się w Davos (Szwajcaria) jako dziecko żydowskich emigrantów, od 1952 roku żyje w Niemczech. W latach 1981-2000 wykładał na uniwersytecie w Heidelbergu, 2000-2005 kierował Instytutem Fritza Bauera - Ośrodkiem Studiów i Dokumentacji Historii i Skutków Holokaustu z siedzibą we Frankfurcie nad Menem. Od 2000 roku jest ponadto profesorem Instytutu Pedagogiki Ogólnej Uniwersytetu Goethego we Frankfurcie, gdzie zajmuje się przede wszystkim teorią wychowania i kształcenia.

${ }^{15}$ M. Brumlik: Wer Sturm sät. Die Vertreibung der Deutschen, Berlin 2005, s. 91-136. Lektura tej publikacji skłania do przypuszczenia, iż Brumlik napisał ją m.in. w związku ze „zmianą frontu“ przez Giordana, dotyczące jej informacje są jednak częściowo błędne; por. ibidem., s. 91 i n. - Giordano, jak napisano powyżej, wygłosił przemówienie w 2004 roku, nie zaś, jak podaje Brumlik, w 2003.

${ }^{16}$ Ibidem, s. 99 i n.

17 Ibidem, s. 99. 
tacja Brumlika jest bardzo typowa dla tendencji, występującej w części historyczno-politycznej publicystyki, częściowo także w naukach historycznych w ostatnich 10-15 latach, sceptycznie spoglądających na nowy kierunek polityki Związku Wypędzonych od końca lat dziewięćdziesiątych, jego ostateczne odejście od programu, skierowanego na rewizję granic i powrót do dawnej ojczyzny oraz zadania, mające na celu większe zaangażowanie $\mathrm{w}$ ochronę narodowych mniejszości, zapobieganie nowym wypędzeniom i kulturę pamięci. Jednym z powodów tej zmiany był fakt, że dzięki tym tematom najwyraźniej udało się organizacjom wypędzonych, które od lat sześćdziesiątych nie były w stanie pozyskać dla swych celów nikogo spoza kręgu ich zaangażowanych członków, powrócić do centrum życia społecznego. Najwyraźniej widać tu też skutki zażartych sporów o nową politykę wschodnia, prowadzonych we wczesnych latach siedemdziesiątych $\mathrm{XX}$ wieku ${ }^{18}$. Typowa dla tego rodzaju sporu wokół Karty wypędzonych jest także próba delegitymizacji działań tych członków związków wypędzonych w okresie wczesnej Republiki Federalnej, którzy byli uprzednio narodowymi socjalistami. Tak więc Micha Brumlik, powołując się na dziennikarza Ericha Spätera $^{19}$, wskazuje np. na fakt, iż $1 / 3$ pierwszych sygnatariuszy Karty niemieckich wypędzonych była oddanymi sprawie nazistami i przyta-

${ }^{18}$ Por. M. Stickler: »Unserer Heimat droht Gefahr!«... oraz idem: »... bis an die Memel«? Die Haltung der deutschen Vertriebenenverbände zur deutsch-polnischen Grenze, w: Granica. Die deutsch-polnische Grenze vom 19. bis zum 21. Jahrhundert, red. K. Gil, Ch. Pletzing. München 2010, s. 105-134.

${ }^{19}$ M. Brumlik: op. cit., s. 100. Erich Später (ur. 1959) jest współpracownikiem Fundacji Heinricha Bölla w Kraju Saary, pisze także głównie dla czasopisma „Konkret“, wydawanego przez niedogmatyczną skrajną lewice (por. Massiver ideologischer Streit zum Nahost-Konflikt unter Linksextremisten, w: Extremismus in Deutschland - Erscheinungsformen und aktuelle Bestandsaufnahme, wyd. Bundesministerium des Innern, Berlin 2006, http:// www.extremismus.com/texte/reader1.pdf [5.12.2010], s. 202 i n.). Später opublikował także broszurę Kein Friede mit Tschechien. Die Sudetendeutschen und ihre Landsmannschaft (Hamburg 2005), w której na s. 83-105 odnosi się do Karty. Jest to wartko napisana odezwa w stylu publicystyki „,antyrewanżystowskiego dyskursu“, wrogiej wobec Związku Wypędzonych i zgodnej z tradycją podobnie formułowanych publikacji NRD i innych państw bloku wschodniego z okresu zimnej wojny; por. obszerne opracowanie M. Sticklera: Vertriebene als »Faschisten", »Revanchisten«, »Kalte Krieger" - ideologiekritische Anmerkungen zur Herkunft eines Vorurteils, w: Zum Ideologieproblem in der Geschichte. Herbert Hömig zum 65. Geburtstag, red. E. Gieseking, I. Gückel, H.-J. Scheidgen, A. Tiggemann, Lauf an der Pegnitz 2006, s. 177-201. 
cza takie nazwiska, jak Rudolf Wagner (1911-2004) ${ }^{20}$, ówczesny rzecznik Ziomkostwa Niemców z Bukowiny, Erik von Witzleben (1884-1958), rzecznik Ziomkostwa Prus Zachodnich oraz Franz Hamm (1900-1988) ${ }^{21}$, przewodniczący Ziomkostwa Niemców z Jugosławii² ${ }^{22}$. Dokładne omówienie tego niewątpliwie ważnego tematu przekroczyłoby ramy niniejszego artykułu, zwłaszcza że nie dysponujemy piśmiennictwem na ten temat, opartym na szerokich podstawach źródłowych. Należy poczekać na wyniki studium, powstającego obecnie w Instytucie Historii Najnowszej (Institut für Zeitgeschichte) ${ }^{23}$.

${ }^{20}$ Rudolfowi Wagnerowi udało się aż do śmierci ukryć nazistowską przeszłość. Jeszcze w 2000 roku kanclerz federalny G. Schröder oddawał mu podczas „Dnia stron ojczystych" cześć jako ostatniemu z żyjących sygnatariuszy Karty ze Stuttgartu; por. Buchenland-Deutscher mit dunkler Vergangenheit, „Münchener Merkur”, 27 grudnia 2006.

${ }^{21}$ Por. M.O. Balling: Von Reval bis Bukarest - Statistisch-Biographisches Handbuch der Parlamentarier der deutschen Minderheiten in Ostmittel und Südosteuropa 1919-1945, t. 1. Kopenhagen 1991, s. 522.

${ }^{22}$ Oprócz wyżej wymienionych Später przywołuje także Gottlieba Leibbrandta, Karla Mockera, Josefa Waltera, Axela de Vries, Ottomara Schreibera, Antona Birknera, Herberta von Bismarcka, Waltera von Keudella, Alfreda Gille'go, Waldemara Krafta, Linusa Kathera oraz Rudolfa Lodgmana von Auena. Oni, a więc połowa spośród 30 sygnatariuszy Karty, nie byli - zdaniem autora - wypędzonymi, lecz nazistowskimi funkcjonariuszami i aktywistami, których biografie „są reprezentatywne dla funkcjonariuszy niemieckich wypędzonych". Pewnych dowodów na poparcie tej tezy Später w większości przypadków jednak nie dostarcza; raczej łagodzi swoje stanowisko, mówiąc, iż jest to jego "ocena“ i wskazuje na brakujące tu wyniki badań; por. M. Später: Kein Friede mit Tschechien..., s. 86.

${ }^{23}$ Spośród przeglądowych opracowań na temat Karty ze Stuttgartu należy jeszcze wymienić: S. Salzborn: Heimatrecht und Volkstumskampf. Außenpolitische Konzepte der Vertriebenenverbände und ihre praktische Umsetzung, Hannover 2001, s. 20-24. Publikacja Samuela Salzborna zasadniczo zgodna jest z wyżej wymienionym „antyrewanżystowskim dyskursem“ i ma na celu delegitymizację działań Związku Wypędzonych. Podobnej argumentacji używa H. Kuhn: »Geist, Volkstum, Heimatrecht « 50 Jahre »Charta der deutschen Heimatvertriebenen « und die eth(n)isch orientierte deutsche Außenpolitik, Hamburg 2000. Por. następnie: T. Weger: »Volkstumskampf« ohne Ende? Sudetendeutsche Organisationen 1945-1955, Frankfurt am Main u.a. 2008, s. 465-476. Także Tobias Weger - wyraźnie pod wpływem tez swego nauczyciela Hansa Henninga Hahna i jego żony Evy Hahn - optuje na pewien sposób za „antyrewanżystowskim“ paradygmatem, przy czym posługuje się tu alienującym terminem „völkisch“ (narodowy), którego jednak nie definiuje i który przez to jest mało selektywny. Por. tu moją recenzję tej publikacji w: „Vierteljahrschrift für Sozial- und Wirtschaftsgeschichte” 2008, t. 95, z. 4, s. 469 z. Por. także K. Nelhiebel: 60 Jahre Charta der deutschen Heimatvertriebenen. Ursprung und Rezeption eines umstrittenen Konzepts, "Zeitschrift für Geschichtswissenschaft“ 2010, z. 9, s. 730-743. Już sam tytuł zdradza tezę artykułu, który - nawiązując do tez Giordano i Brumlika - jest przede wszystkim opinią na temat koncepcji Fundacji „Ucieczka, Wypędzenie, Pojednanie". Kurt Nelhiebel jest z urodzenia sudeckim Niemcem, pracował 
W dalszej części zostanie podjęta próba poważnego potraktowania wspomnianego wyżej postulatu Michy Brumlika, aby zinterpretować Kartę niemieckich wypędzonych ze stron ojczystych jako dokument tamtych czasów, w kontekście warunków, w jakich powstała. Ważne jest przy tym uświadomienie sobie podłoża, na którym powstał ten dokument oraz przede wszystkim uwzględnienie faktu, iż organizacje wypędzonych wbrew temu, co starały się demonstrować na zewnątrz, od początku wcale nie były wspólnie działającymi grupami nacisku z jednakowymi intencjami i jasno określonym planem działania. Były one raczej w najwyższym stopniu partykularnie zorganizowanymi stowarzyszeniami, których możliwości oddziaływania ograniczały w pewnym stopniu wewnętrzne konflikty.

\section{Początki stowarzyszeń wypędzonych w Niemczech}

Partykularyzm organizacji wypędzonych był także i przede wszystkim skutkiem niezwyczajnej historii ich powstania. Tworzą one specyficzny element systemu politycznego Republiki Federalnej Niemiec. Choć i inne zachodnie państwa demokratyczne Europy, jak Finlandia i Austria ${ }^{24}$ (na skutek II wojny światowej), czy też Holandia i Francja

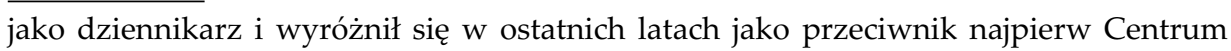
przeciwko Wypędzeniom, a następnie Fundacji. Por. tu także jego polemiczny artykuł: Die Entkopplung von Krieg und Vertreibung - Zu Manfred Kittels Deutung der jüngeren europäischen Geschichte, "Zeitschrift für Geschichtswissenschaft“ 2010, z. 1, s. 54-69. Por. także E. Hahn, H. Henning Hahn (red.): Die Vertreibung im deutschen Erinnern. Legenden, Mythos, Geschichte, Paderborn-München-Wien-Zürich 2010, s. 443-448. Natomiast pozytywnie ocenia Kartę specjalista prawa międzynarodowego Alfred M. de Zayas w swojej publikacji Die deutschen Vertriebenen. Keine Täter - sondern Opfer. Hintergründe, Tatsachen, Folgen, Graz 2006, s. 193-199 (chodzi tu o wznowienie książki Anmerkungen zur Vertreibung der Deutschen aus dem Osten, która ukazała się po raz pierwszy w 1986 roku) oraz politolożka Marion Frantzjoch-Immenkeppel, która w 1999 roku mówiła o „wzorcu politycznej kultury“ i godnym uwagi „dokumencie rezygnacji z przemocy“; por. Vertrieben in Nachkriegsdeutschland. Die Integration der Deutschen aus dem Osten und ihr Einfluss auf die Bundesrepublik Deutschland, w: H.-M. Hinz (red.): Zuwanderungen - Auswanderungen. Integration und Desintegration nach 1945, Wolfratshausen 1999, s. 145-185, tutaj s. 155. Po polskiej stronie przeważają krytyczne opinie na temat Karty; por. np. J.M. Piskorski: Vertreibung und deutsch-polnische Geschichte. Eine Streitschrift, Osnabrück 2005, s. 36.

${ }^{24}$ Por. M. Stickler: Vertriebenenintegration in Österreich und Deutschland - ein Vergleich, w: M. Gehler, I. Böhler (red.): Verschiedene europäische Wege im Vergleich. Österreich und die Bundesrepublik Deutschland 1945/49 bis zur Gegenwart. Festschrift für Rolf Steininger zum 65. Geburtstag, Innsbruck 2007, s. 416-435. 
(w następstwie upadku kolonialnych mocarstw), miały poważne problemy z przyjęciem i asymilacją uchodźców oraz wypędzonych ${ }^{25}$, a ci oczywiście tworzyli polityczne organizacje, tylko w Niemczech powstał tak bardzo zróżnicowany i - szczególnie w zewnętrznej percepcji - wpływowy system organizacji.

W latach 1945/1946 napłynęło do czterech stref okupacyjnych na ziemiach, które pozostały przy Niemczech, około $12 \mathrm{mln}$ osób - najpierw na skutek ucieczki i "dzikich wypędzeń", następnie w konsekwencji "zgodnych z przepisami i humanitarnych transportów”, uchwalonych na konferencji poczdamskiej. W 1950 roku mieszkało w ówczesnej Republice Federalnej około 8 mln wypędzonych, co stanowiło 16,1\% liczby ludności. $W$ poszczególnych krajach związkowych ich udział był początkowo jeszcze większy i wynosił np. w 1946 roku w Dolnej Saksonii 23,4\%, w Bawarii 18,9\%, a w Szlezwiku-Holsztynie 32,2\% ${ }^{26}$. Nie do przecenienia są wynikające $\mathrm{z}$ tego zmiany $\mathrm{w}$ strukturze społecznej oraz kulturze politycznej Niemiec Zachodnich - istniejące wtedy tendencje do konserwatywnej rekonstrukcji zostały wzmocnione, nie bez racji mówiono w tym kontekście o modernizacyjnym impulsie pod znakiem konserwatyzmu ${ }^{27}$. Ludność miejscowa częstokroć odbierała imigrację jako zmasowaną inwazję obcych, przez co ludność napływowa najczęściej nie była chętnie witana ${ }^{28}$. Ówczesne określenie wypędzonych jako „piątego stanu“29, ukute przez znanego polityka z kręgów wypędzo-

${ }^{25} \mathrm{Na}$ temat powstania i oceny pojęcia „wypędzonych“ por. obszerne opracowanie M. Beera: Flüchtlinge, Ausgewiesene, Neubürger, Heimatvertriebene, Flüchtlingspolitik und Flüchtlingsintegration in Deutschland nach 1945, begriffsgeschichtlich betrachtet, w: M. Beer et al. (red.): Migration und Integration. Aufnahme und Eingliederung im historischen Wandel, Stuttgart 1997, s. 145-167 oraz Ph. Thera: Deutsche und polnische Vertriebene. Gesellschaft und Vertriebenenpolitik in der SBZ/DDR und in Polen 1945-1956, Göttingen 1998, s. 88-100.

${ }^{26}$ Por. dane z: G. Reichling: Die deutschen Vertriebenen in Zahlen, cz. 2, Bonn 1989, s. 30 i 32. Podobnie oficjalna statystyka z pierwszej i decydującej fazy integracji wypędzonych w: E. Lemberg et al. (red.): op. cit. Przeglądowo por. także D. Hoffmann, M. Krauss, M. Schwartz (red.): Vertriebene in Deutschland. Interdisziplinäre Ergebnisse und Forschungsperspektiven, München 2000.

${ }^{27}$ Por. P. Waldmann: Die Eingliederung der ostdeutschen Vertriebenen in die westdeutsche Gesellschaft, w: J. Becker, T. Stammen, P. Waldmann (red.): Vorgeschichte der Bundesrepublik Deutschland. Zwischen Kapitulation und Grundgesetz, München 1979, s. 163-192, tutaj s. 188.

${ }^{28}$ Por. szczególnie A. Kossert: Kalte Heimat. Die Geschichte der deutschen Vertriebenen nach 1945, München 2008.

${ }^{29}$ H. Pütz (oprac.): Konrad Adenauer und die CDU der britischen Besatzungszone. 1946-1949 , Bonn 1975, s. 601. 
nych Linusa Kathera (1893-1983) ${ }^{30}$ i celowo budzące skojarzenia z walką klasową wskazywało na potężny polityczny i społeczny ładunek wybuchowy, który zdawał się tu gromadzić. $Z$ tego też powodu zachodni sojusznicy odmawiali z początku wypędzonym prawa do tworzenia koalicji, z obawy przed radykalizacją tej licznej, zdeklasowanej grupy społecznej ${ }^{31}$. Dopiero w 1949 roku, kiedy system polityczny powstającej Republiki Federalnej był już w najważniejszych zarysach ukonstytuowany, można było tworzyć w skali poszczególnych stref okupacyjnych względnie ogólnokrajowej zrzeszenia licznych lokalnych organizacji wypędzonych, ukrywających się pod różnymi przykrywkami. W tym sensie stowarzyszenia wypędzonych były „spóźnialskimi”32, którzy musieli znaleźć swoje miejsce $\mathrm{w}$ istniejącym już partyjno-administracyjnym systemie państwowym. Z tej początkowej dyskryminacji wynika w dużym stopniu fakt, że wypędzeni przez całe lata byli organizacyjnie podzieleni. Oprócz zbudowanego na wzór związków zawodowych Centralnego Związku Wypędzonych Niemców (Zentralverband vertrie-

${ }^{30}$ Kather (1893-1983) pochodził z katolickiej Warmii w Prusach Wschodnich. Do 1933 roku był członkiem Niemieckiej Partii Centrum. W latach pięćdziesiątych XX wieku należał do najbardziej znanych oraz najskuteczniejszych polityków z kręgu wypędzonych, walczących o wyrównanie szkód. Współzałożyciel i długoletni przewodniczący organizacji wypędzonych ZvD, następnie BVD. Jako poseł do Bundestagu 1949-1957 należał początkowo do CDU, następnie rozczarowany tym, że Adenauer nie powołał go do żadnego swojego rządu, przeszedł w 1954 roku do Bloku Wypędzonych ze Stron Ojczystych i Pozbawionych Praw (BHE). Powodem tego, że Kather nigdy nie awansował na wysokie stanowisko, co oznaczało według niego - ministerialne, oraz że po utworzeniu Związku Wypędzonych odsunięto go i nie otrzymał już nigdy żadnej kierowniczej funkcji, był głównie jego egocentryczny, podporządkowany ambicji charakter, który nie pozwalał mu tolerować innych „bóstw” obok niego i czynił go niezdolnym do współdziałania. Błędnie nakierowana ambicja skłoniła go pod koniec lat sześćdziesiątych do próby powrotu na polityczną scenę, tym razem w NPD, od której jednak odwrócił się już na początku lat siedemdziesiątych. Jeszcze za życia popadł w zapomnienie. Jego obszerna spuścizna znajduje się w Archiwum Polityki Chrześcijańsko-Demokratycznej w Sankt Augustin. Dotychczas nie powstała biografia tej kontrowersyjnej, choć ważnej postaci z początków Republiki Federalnej. Jego pisany na wzór pamiętnika dwutomowy manifest Die Entmachtung der Vertriebenen (München 1964 i 1965) jest co prawda ważnym źródłem, jednak nie należy go bezkrytycznie używać, jako że przepojony jest urażoną ambicją oraz animozjami wobec faktycznych i domniemanych przeciwników.

${ }^{31}$ Niemniej jednak powstawały liczne utajnione organizacje, por. tutaj oraz przeglądowo nt. początków zachodnioniemieckich stowarzyszeń wypędzonych obszerne opracowanie B. Sonnewalda: Die Entstehung und Entwicklung der ostdeutschen Landsmannschaften von 1947-1952, Berlin 1975.

${ }^{32}$ M.M. Wambach: Verbändestaat und Parteienoligopol. Macht und Ohnmacht der Vertriebenenverbände, Stuttgart 1971, s. 23. 
bener Deutscher, ZvD), który w 1954 roku przemianował się na Związek Wypędzonych Niemców (Bund vertriebener Deutscher, BVD), istniała oddzielna centrala tzw. ziomkostw - Zjednoczenie Ziomkostw Wschodnioniemieckich (Vereinigte Ostdeutsche Landsmannschaften, VOL), od 1952 roku pod nazwą Zjednoczenia Ziomkostw (Verband der Landsmannschaften, VdL), podkreślających wspólne pochodzenie i usiłujących kontynuować stosunki, panujące $\mathrm{w}$ ich dawnych ojczyznach. Poza tym powstał w 1950 roku jeszcze Blok Wypędzonych ze Stron Ojczystych i Pozbawionych Praw (Bund der Heimatvertriebenen und Entrechteten, BHE) ${ }^{33}$ - od 1952 roku pod nazwą Bloku Wszechniemieckiego (Gesamtdeutscher Block-BHE), będący własną partią wypędzonych, reprezentowaną w latach pięćdziesiątych w większości zachodnioniemieckich landtagów, a w okresie 1953-1957 także w Bundestagu. W dłuższej perspektywie BHE jednak nie utrzymała się. Pomimo okresowego zjednoczenia z Partią Niemiecką (Deutsche Partei, DP) pod wspólną nazwą Partii Wszechniemieckiej (Gesamtdeutsche Partei, GDP) utraciła w latach sześćdziesiątych polityczne znaczenie na skutek porażek wyborczych. Utworzenie wspólnej centrali wszystkich organizacji wypędzonych nie udało się także w niemałym stopniu $\mathrm{z}$ powodu osobistej rywalizacji działaczy. $\mathrm{W}$ ten sposób stowarzyszenia wypędzonych odsłaniały swe flanki i dały przede wszystkim rządowi federalnemu możliwość wygrywania jednych przeciwko drugim $\mathrm{w}$ myśl polityki divide et impera oraz osłabienia ich roli w bieżącym życiu politycznym. Dopiero 27 października 1957 roku (względnie ostatecznie 14 grudnia 1958), kiedy malała już liczba członków, udało się stworzyć wspólne stowarzyszenie ziomkostw i związków krajowych pod nazwą Związek Wypędzonych (Bund der Vertriebenen. Vereinigte Landsmannschaften und Landesverbände, BdV). Jednak wówczas organizacje wypędzonych miały swój punkt kulminacyjny już za sobą. Na początku lat pięćdziesiątych ZvD i VOL liczyły łącznie 3-4 mln członków. Na skutek starań o integrację, szczególnie zaś dzięki skutecznej ustawie o wyrównaniu szkód, ta imponująca liczba skurczyła się na początku lat sześćdziesiątych do 2,3 mln, co i tak zresztą stanowiło pokaźny poziom organizacyjnej przynależności rzędu 20-25\% ${ }^{34}$.

\footnotetext{
${ }^{33}$ Por. F. Neumann: Der Block der Heimatvertriebenen und Entrechteten...

${ }^{34}$ Por. M. Stickler: »Ostdeutsch heißt Gesamtdeutsch«..., s. 136-148.
} 


\section{Powstanie Karty niemieckich wypędzonych ze stron ojczystych}

Całkiem nieprzypadkowo ZvD i VOL bezpośrednio po ich utworzeniu spotkały się 5-6 sierpnia 1950 roku w Stuttgarcie na wspólnym wiecu, aby ogłosić Kartę niemieckich wypędzonych ze stron ojczystych. Oba konkurujące ze sobą zrzeszenia chciały tą potężną wspólną manifestacją zakamuflować istniejące między nimi różnice, które wyszły na jaw, oraz zapewnić sobie pozycje partnera w systemie politycznym młodej Republiki Federalnej. Droga do tego była dość trudna. 20 listopada 1949 roku oba zrzeszenia zobowiązały się w umowie z Getyngi (Göttinger Abkommen) ${ }^{35}$ do współpracy, przy czym uzgodniono następujące punkty:

- Jedność i zgoda obu stowarzyszeń. Zasadniczo ZvD i jego organizacje landowe miały przejąć zadania społeczne i gospodarczo-polityczne, zaś ziomkostwa - zadania kulturalne i związane z „polityką małych ojczyzn” („Heimatpolitik”).

- Chciano uczynić wszystko, aby także w przyszłości uzyskiwać i zabezpieczać pełną zgodę bez stosowania uniformizujących uregulowań oraz uwzględniając to, co powstaje w naturalny sposób Oznaczało to, że oba stowarzyszenia $\mathrm{w}$ początkowym okresie miały nadal istnieć równolegle.

- „Uczestniczące strony formułują swe wspólne postulaty i cele w Magna Carta wypędzonych z ojczystych stron. Podjęto organizacyjne działania, służące realizacji tego zamiaru"36.

Cytowane na koniec postanowienie tworzyło podstawę do wypracowania Karty niemieckich wypędzonych ${ }^{37}$; która miała być „protestem przeciwko niesprawiedliwości wypędzenia oraz manifestacją dobrej woli i gotowości do uczestnictwa w pracy nad nowymi Niemcami i Europą" ${ }^{38}$. Żądania wypędzonych - prawo do powrotu i rewizja granic, wynikające $\mathrm{z}$ „Heimatpolitik“, nie zostały więc wcale poniechane,

\footnotetext{
${ }^{35}$ Por. ibidem, s. 41 i n.

${ }^{36}$ Cyt. ibidem, s. 437.

${ }^{37}$ Por. T. Weger: op. cit., s. 465-476.

${ }^{38}$ L. Kather: op. cit., t. 1, s. 168.
} 
co zresztą było zgodne z ówczesnym konsensusem w polityce niemieckiej, łączącym wszystkie partie z wyjątkiem $\mathrm{KPD}^{39}$. Powiązano je jednak z celem zjednoczenia Europy, aby odsunąć podejrzenie o zręczny powrót do nacjonalistycznej przeszłości ${ }^{40}$. W lutym 1950 roku powstała komisja przygotowawcza, przy której obsadzaniu przestrzegano parytetu pomiędzy ZvD i VOL. ZvD reprezentował federalny prezes Carl Dederra, Wilhelm Drescher z Dolnej Saksonii oraz przewodniczący krajowego związku Josef Walter z Hesji ${ }^{41}$. Przedstawicielami ziomkostw byli Walter Gille z Prus Wschodnich ${ }^{42}$ i Axel de Vries ${ }^{43}$ jako reprezentant Ziomkostwa Niemców Bałtyckich. Ponieważ komisja wkrótce została sparaliżowana przez toczone w niej spory, rozszerzono ją. Przyjęto następnych czołowych polityków obu stowarzyszeń, jak przewodniczącego ZvD Linusa Kathera, przewodniczącego regionalnej organizacji ZvD w Badenii-Wirtembergii Karla Mockera ${ }^{44}$ oraz jego odpowiednika w Dolnej Saksonii Helmutha Gossinga ${ }^{45}$. Ze strony ziomkostw dołączyli Rudolf Lodgman von Auen ${ }^{46}$ (Ziomkostwo Niemców Sudeckich), Walter Rinke $^{47}$ (Ziomkostwo Śląsk) i Walter von Keudell ${ }^{48}$ (Ziomkostwo Berlin-Brandenburg). Ważną rolę odgrywał także Ottomar Schreiber ${ }^{49}$ z Kłajpedy, rzecznik Ziomkostwa Prus Wschodnich i sekretarz stanu w Federalnym Ministerstwie ds. Wypędzonych. Wśród tych 12 osób w 1950 roku dwie (Kather i Keudell) należały do CDU, jedna (Rinke) do CSU, cztery do BHE (Mocker, Gossing, Walter, Gille), jedna do FDP (de Vries), a cztery (Dederra, Drescher, Lodgman i Schreiber) były bezpartyjne. Patrząc na skład tego gremium pod kątem przynależności do ziomkostw, narzuca się uwaga, iż wyraźną przewagę mieli Niemcy sudeccy (Dederra, Walter, Mocker i Lodgman), podobnie Niemcy z Prus Wschodnich

\footnotetext{
${ }^{39}$ Por. obszernie T. Stickler: »Ostdeutsch heißt Gesamtdeutsch«..., s. 209-346.

${ }^{40}$ Por. M.H. Boehm: Gruppenbildung und Organisationswesen, w: H. Lemberg et al. (red.): op. cit., t. 1, s. 521-605, tutaj: s. 581.

${ }^{41}$ Por. notka biograficzna w: T. Weger: »Volkstumskampf«, s. 632.

42 Por. ibidem, s. 595.

${ }^{43}$ Por. ibidem, s. 590 oraz M.O. Balling: Von Reval bis Bukarest, t. 1, s. 126.

${ }^{44}$ Por. notka biograficzna w: T. Weger: op. cit., s. 615.

${ }^{45}$ Por. ibidem, s. 596.

${ }^{46}$ Por. ibidem, s. 612 i n. oraz M.O. Balling: Von Reval bis Bukarest, t. 1, s. 328.

${ }^{47}$ Por. notka biograficzna w: T. Weger: »Volkstumskampf«, s. 621.

${ }^{48}$ Por. ibidem, s. 606.

${ }^{49}$ Por. ibidem oraz M.O. Balling: Von Reval bis Bukarest, t. 2, s. 723.
} 
(Gille, Kather, Gossing, Schreiber). Pozostałe ziomkostwa były reprezentowane przez pojedyncze osoby: Śląsk (Rinke), Berlin-Brandenburg (Keudell) i Niemcy bałtyccy (de Vries). Dwóch członków komisji było przedtem aktywnymi narodowymi socjalistami, mianowicie Gille (od 1937 roku) i Walter (od 1939 roku, przedtem w Partii Niemców Sudeckich). Członkiem tej partii był także Mocker, który w 1971 roku przystąpił do CDU, po tym, jak ostatecznie rozpadł się Blok Wypędzonych ze Stron Ojczystych i Pozbawionych Praw (BHE). Natomiast rola de Vriesa jako członka niemieckiej administracji wojskowej w okupowanej Białorusi podczas II wojny światowej pozostaje do dziś nie do końca wyjaśniona ${ }^{50}$. Rozszerzona komisja wypracowała w następnych miesiącach tekst, który pod wieloma względami miał charakter kompromisu, gdyż należało uzgodnić bardzo odmienne stanowiska pomiędzy ZvD i VOL, panujące także wewnątrz obu organizacji ${ }^{1}$.

\section{Ogłoszenie Karty niemieckich wypędzonych ze stron ojczystych}

Datę ogłoszenia Karty niemieckich wypędzonych (5-6 sierpnia 1950) wybrano z pełną świadomością - prawie dokładnie pięć lat po podpisaniu protokołu poczdamskiego, legalizującego wypędzenie niemieckiej ludności z niemieckich terenów wschodnich oraz Polski, Czechosłowacji

${ }^{50}$ Por. Ch. Gerlach: Kalkulierte Morde. Die deutsche Wirtschafts- und Vernichtungspolitik in Weißrussland 1941 bis 1944, Hamburg 1999, głównie s. 686 i n.

${ }^{51}$ Axel de Vries twierdził, że jest jednym z głównych autorów tekstu Karty, czemu jednak następnie zaprzeczył Kather; por. L. Kather: op. cit., t. 1, s. 169. Natomiast Franz Hamm, w 1950 roku przewodniczący Ziomkostwa Niemców z Jugosławii i jeden z sygnatariuszy Karty, potwierdził w 1986 roku faktyczne autorstwo de Vriesa; por. A.F. de Zayas: op. cit., s. 197. Spór o autorstwo Karty należy oceniać w kontekście rywalizacji pomiędzy ZvD i VOL, co widać szczególnie wyraźnie we wspomnieniach Kathera. Przeciwko autorstwu de Vriesa przemawia fakt, że w ostatecznym tekście Karty można znaleźć wyraźne podobieństwa z tzw. Deklaracją adwentową z Eichstätt (Eichstätter Adventsdeklaration). Została ona uchwalona 27 listopada 1949 roku przez grupę polityków i naukowców z wszystkich politycznych obozów Niemców sudeckich, którzy na zaproszenie Wspólnoty Ackermanna, stowarzyszenia katolickich Niemców sudeckich, zebrali się w bawarskim Eichstätt; por. K. Nelhiebel: 60 Jahre Charta der deutschen Heimatvertriebenen, s. 232-235 oraz B. Kohler: Schon vor sechzig Jahren wollten die Vertriebenen nicht Vergeltung, sondern Gerechtigkeit, „Frankfurter Allgemeine Zeitung“, 27 listopada 2009, s. 12. 
i Węgier. Stuttgart zaś dlatego wybrano jako miejsce wydarzenia, gdyż Karl Mocker i jego regionalna organizacja ZvD w (Północnej) Wirtembergii $^{52}$ byli gotowi i mogli przygotować u siebie masowy zjazd o dużej sile oddziaływania ${ }^{53}$. W pierwszym wiecu $\mathrm{w}$ dniu 5 sierpnia $\mathrm{w}$ domu zdrojowym w Bad Cannstatt (dzielnica Stuttgartu) wzięło udział około 1000 zaproszonych gości. Zainscenizowano coś w rodzaju plebiscytu, w którym obecni przedstawiciele wypędzonych oklaskami przyjęli Kartę. Jej tekst odczytał „nieznany uciekinier“ Manuel Jordan z Górnego Śląska ${ }^{54}$. Jako reprezentant rządu federalnego pojawił się wicekanclerz Franz Blücher (FDP) ${ }^{55}$; obecni byli także przedstawiciele Wysokich Komisarzy. Oprócz Blüchera przemawiali także reprezentanci ZvD (Kather) i VOL (Schreiber). Dzień później, 6 sierpnia odbyła się przed ruinami Nowego Zamku w centrum Stuttgartu wielka manifestacja, w której brało udział około 100 tys. osób i podczas której powtórzono ogłoszenie Karty, tym razem przed liczną publicznością. Na ogromnej mapie przedstawiono utracone ziemie ojczyste wypędzonych, przez co wyraźnie ukazano cel - powrót i związana z nim rewizja granic ${ }^{56}$. $\mathrm{Na}$ tym wiecu przemawiał $\mathrm{w}$ imieniu rządu federalnego minister fede-

${ }^{52}$ Pierwotnie ZvD posiadał w dzisiejszej Badenii-Wirtembergii - do 1952 roku obejmującej kraje (Północnej) Wirtembergii-(Północnej) Badenii, (Południowej) Badenii i (Południowej) Wirtembergii-Hohenzollern - cztery regionalne organizacje: w Północnej Badenii, (Północnej) Wirtembergii, Południowej Badenii i (Południowej) Wirtembergii-Hohenzollern-Lindau.

${ }^{53}$ Interesujący jest fakt, że opisy dokładnego przebiegu ogłoszenia Karty po dziś dzień istotnie różnią się w szczegółach. W dalszym ciągu tekstu powołuję się w dużym stopniu na opis Kathera, który był przecież ważnym świadkiem, pochodzący z początku lat sześćdziesiątych; por. L. Kather: op. cit., t. 1, s. 169-171. Por. także de Zayas: op. cit., s. 193-196 oraz A.F. Weger: op. cit., s. 470-473.

${ }^{54}$ Kather upatrywał w tym sprytny wybieg ziomkostw, szczególnie de Vriesa, który miał zapobiec formalnemu ogłoszeniu Karty przez przewodniczącego ZvD; por. L. Kather: op. cit., t. 1, s. 169. W każdym razie jest to kolejny dowód na rywalizację obu stowarzyszeń, rzucającą cień na ważne wydarzenie.

${ }^{55}$ Według Kathera w zaproszeniach zapowiedziany był kanclerz Konrad Adenauer jako główny mówca, „jednak odmówił, jak to często robił”; por. L. Kather: op. cit., t. 1, s. 170. Najwyraźniej Adenauer ze względu na ówczesną napiętą sytuację międzynarodową nie chciał występować na politycznej scenie wypędzonych. Tę interpretację potwierdza fakt, że także Blücher wygłosił raczej niewiele mówiące przemówienie; por. T. Weger: op. cit., s. 471.

${ }^{56}$ Por. ilustracja w: Haus der Heimat der Landes Baden-Württemberg (wyd.): Umsiedlung, Flucht und Vertreibung der Deutschen als internationales Problem. Zur Geschichte eines europäischen Irrwegs, Stuttgart 2002, s. 29. 
ralny ds. wypędzonych Hans Lukaschek (CDU), którego Kather uważał za osobistego wroga ${ }^{57}$. Następnie zabrali głos nadburmistrz Stuttgartu Arnulf Klett (bezpartyjny), minister spraw wewnętrznych Wirtembergii-Badenii Fritz Ulrich (SPD), Kather jako przewodniczący ZvD oraz Josef Walter i Karl Mocker z ramienia regionalnych organizacji ZvD w Hesji i (Północnej) Wirtembergii. Po wiecu odbyło się przyjęcie w wilii Reitzenstein, zorganizowane przez rząd Wirtembergii-Badenii, podczas którego Kather oraz przedstawiciele ZvD i ziomkostw uroczyście podpisali Kartę ${ }^{58}$, przy czym, co charakterystyczne, istnieją dwa oryginalne egzemplarze - jeden dla ZvD i jeden dla VOL.

Od czasów wiecu w Stuttgarcie organizacje wypędzonych organizowały zawsze około 5-6 sierpnia tzw. Dzień stron ojczystych, który w latach pięćdziesiątych przesunięto na korzystniejszy termin na początku września. Co prawda nie chodzi tu o święto państwowe, niemniej jed-

${ }^{57}$ Por. M. Stickler: »Ostdeutsch heißt Gesamtdeutsch«..., s. 55-66.

${ }^{58}$ L. Kather: op. cit., t. 1, s. 173. Sygnatariuszami byli: dr Linus Kather, przewodniczący ZvD; dr Rudolf Lodgman von Auen, rzecznik Ziomkostwa Niemców sudeckich; Axel de Vries, rzecznik Ziomkostwa Niemców Bałtyckich; Josef Walter, przewodniczący Krajowego Związku Wypędzonych w Hesji; Erwin Tittes, rzecznik Ziomkostwa Saksończyków Siedmiogrodzkich w Niemczech; Franz Hamm, przewodniczący Ziomkostwa Niemców z Jugosławii; Helmut Gossing, przewodniczący Związku Dolnej Saksonii w ZvD; dr Rudolf Wagner, rzecznik Ziomkostwa Przesiedlonych Niemców z Bukowiny; dr Karl Bartunek, Krajowy Związek Wypędzonych Niemców w Północnej Badenii; dr Karl Mocker, przewodniczący Krajowego Związku Wypędzonych Niemców w Wirtembergii; dr Alfred Rojek, przewodniczący Berlińskiego Krajowego Związku Wypędzonych; dr Ottomar Schreiber, rzecznik Ziomkostwa Prus Wschodnich; H. Eschenbach, Krajowy Związek Wypędzonych Niemców w Stuttgarcie; Walter von Keudell, rzecznik Ziomkostwa Berlin-Brandenburg; Erik von Witzleben, rzecznik Ziomkostwa Prus Zachodnich; dr Alfred Gille, przewodniczący Krajowego Związku Wypędzonych w Szlezwiku-Holsztynie; dr Konrad Winkler, przewodniczący Wspólnoty Wypędzonych w Południowej Badenii; dr Walter Rinke, rzecznik Ziomkostwa Śląsk; dr Bernhard Geisler, przewodniczący Krajowego Związku Wypędzonych ze Wschodu w Nadrenii Północnej-Westfalii; Waldemar Kraft, rzecznik Ziomkostwa Wisła-Warta; Anton Birkner, rzecznik Ziomkostwa Karpatoniemieckiego; Erwin Engelbrecht, przewodniczący Krajowego Związku Bawarii w ZvD; Herbert v. Bismarck, rzecznik Ziomkostwa Pomorskiego; dr Gottlieb Leibbrandt, rzecznik Arbeitsgemeinschaft der Ostumsiedler; A. Deichmann, przewodniczący Krajowego Związku Wypędzonych Niemców w Nadrenii-Palatynacie; Roman Herlinger, Hauptausschuss der Flüchtlinge und Ausgewiesenen in Bayern; dr Erich Kautzor, przewodniczący Stowarzyszenia Wypędzonych w Wirtembergii, Hohenzollern i Lindau; Wilhelm Zeisberger, Neubürgerbund, Bawaria; Erich Luft, Krajowy Związek Bawarii w ZvD; dr Kimme, przewodniczący Krajowego Związku Wypędzonych Niemców w Bremie. 
nak Dzień odgrywa centralną rolę w działalności publicznej związków wypędzonych. W odróżnieniu od spotkań ziomkostw, odbywających się najczęściej na wiosnę, „Dni stron ojczystych” nie miały względnie nie mają charakteru centralnych manifestacji, lecz organizowane są na całym terytorium Republiki Federalnej, gdzie przygotowują je lokalne organizacje wypędzonych. Ta strategia miała na celu ogólnokrajową mobilizację wypędzonych, którzy dzięki temu nie musieli przedsiębrać dalekich podróży, jednocześnie na prowincji występowali także prominentni politycy z kręgów wypędzonych. Taka regionalizacja miała też ułatwić włączenie lokalnej ludności i pozyskiwanie jej dla celów stowarzyszeń wypędzonych ${ }^{59}$.

Manifestacja w Stuttgarcie i ogłoszenie Karty niemieckich wypędzonych ze stron ojczystych były dla organizacji wypędzonych prestiżowym sukcesem, którego znaczenia nie da się przecenić. Pierwszy raz od uchylenia zakazu stowarzyszania się zabrały głos i dobitnie wyraziły żądanie stania się ważnym elementem politycznego systemu młodej Republiki Federalnej. Ogromne znaczenie dla długofalowego znaczenia Karty miał fakt, że klasa polityczna w Republice Federalnej, reprezentująca wszystkie partie, a także DGB, identyfikowały się z tekstem Karty ${ }^{60}$. Tutaj procentowało to, że ZvD i VOL nie były umocowane na partyjnej scenie i utrzymywały dobre stosunki z wszystkimi demokratycznymi partiami ${ }^{61}$. Jeśli nawet wśród autorów Karty nie znalazł się żaden socjaldemokrata, to jej tekst popierał także i ten ważny segment środowiska wypędzonych. Jej zwolennikami byli przede wszystkim sudeckoniemieccy socjaldemokraci jak Wenzel Jaksch ${ }^{62}$, ówczesny

\footnotetext{
${ }^{59}$ Por. M. Stickler: »Ostdeutsch heißt Gesamtdeutsch«..., s. 160 i n.

${ }^{60}$ Por. L. Kather: op. cit., t. 1, s. 173; por. także E. Hahn, H. Henning Hahn (red.): op. cit., s. $448-455$.

${ }^{61}$ Por. M. Stickler: »Ostdeutsch heißt Gesamtdeutsch «..., s. 209-346.

${ }^{62}$ Wenzel Jaksch (1896-1967) pochodził z południowych Czech. W 1913 roku przyłączył się do niemiecko-austriackiej socjaldemokracji. Po 1918 roku należał do Niemieckiej Socjaldemokratycznej Partii Robotniczej w Republice Czechosłowackiej, z ramienia której zasiadał w latach 1929-1938 w parlamencie. W 1938 roku został jej przewodniczącym. W 1939 roku wyemigrował do Wielkiej Brytanii, następnie po II wojnie światowej, kiedy zabroniono mu powrotu do Czechosłowacji - do Niemiec Zachodnich. Jaksch należał do głównych osobistości Ziomkostwa Niemców Sudeckich, był współzałożycielem socjaldemokratycznej Wspólnoty Seligera, a od 1959 roku przewodniczącym Zgromadzenia Federalnego Niemców Sudeckich. Od 1964 roku do śmierci był przewodniczą-
} 
kierownik heskiego Urzędu krajowego ds. wypędzonych, uchodźców i ewakuowanych, a od 1951 roku pierwszy przewodniczący Wspólnoty Seligera, organizacji socjaldemokratów, pielęgnującej tradycje sudeckich Niemców. Już wówczas krytykowano w SPD politykę sudeckoniemieckich socjaldemokratów, szczególnie ich gotowość do współpracy w ramach organizacji wypędzonych $\mathrm{z}$ dawnymi narodowymi socjalistami. Poseł do Bundestagu z ramienia SPD Ernst Paul ${ }^{63}$ uzasadniał po latach to postępowanie wspólnym doświadczeniem wypędzenia: „Twierdzę, że wypędzenie uczyniło nas towarzyszami doli i niedoli. Gdybyśmy mogli byli pozostać w Kraju Sudeckim lub mogli tam powrócić, wtedy zapewne różnice między nami miałyby wymiar polityczny. Teraz jednak, gdy łączy nas wspólny los, trzeba być gotowym, żeby usiąść razem z kimś, z kim przedtem nie rozmawiało się" ${ }^{\prime 64}$.

\section{Treść Karty niemieckich wypędzonych}

Jak zasygnalizowano powyżej, głównym celem Karty ze Stuttgartu było powiązanie postulatów wypędzonych, czyli prawa do powrotu i rewizji granic, z uroczystą "rezygnacją z zemsty i odwetu“ oraz dążeniem do zjednoczonej Europy. Jako polityczny sygnał Karta skierowana była nie tylko w stronę zagranicy, ale także i głównie do mieszkańców Republiki Federalnej. Poniżej cytowany jest jej tekst oraz fragment po fragmencie komentowany.

cym Związku Wypędzonych. Od 1953 roku poseł do Bundestagu. Por. głównie M. Schumacher (red.): M.d.B. Volksvertretung im Wiederaufbau 1946-1961. Bundestagskandidaten und Mitglieder der westzonalen Vorparlamente. Eine biographische Dokumentation, Düsseldorf 2000, s. 186; M.K. Bachstein: Wenzel Jaksch und die sudetendeutsche Sozialdemokratie, Wien 1974; H.W. Martin: ...»nicht spurlos aus der Geschichte verschwinden«. Wenzel Jaksch und die Integration der sudetendeutschen Sozialdemokraten in die SPD nach dem II. Weltkrieg (1945-1949), Frankfurt am Main 1996; Seliger-Gemeinde (red.): Reden zum Gedenken an Wenzel Jaksch (1896-1966). Wegbereiter deutscher Ostpolitik. Fernwald 1998. Dotychczas nie ukazała się naukowo opracowana biografia tego wybitnego socjaldemokraty.

${ }^{63}$ Ernst Paul (1897-1978) pochodził z Kraju Sudeckiego. W 1939 roku zmuszony przez nazistów do emigracji, uciekł do Szwecji i stamtąd występował przeciwko wypędzaniu Niemców sudeckich. Po wojnie Paul pracował jako niezależny dziennikarz w Badenii-Wirtembergii. W latach 1949-1969 był posłem do Bundestagu.

${ }^{64}$ Por. Abgeordnete des Deutschen Bundestages. Aufzeichnungen u. Erinnerungen, wyd. Deutscher Bundestag, t. 2, Boppard-Rhein 1983, s. 161 i n. 
„Świadomi odpowiedzialności przed Bogiem i ludźmi, świadomi przynależności do chrześcijańskiego, zachodnioeuropejskiego kręgu kulturowego, świadomi przynależności do narodu niemieckiego oraz w zrozumieniu wspólnego celu wszystkich narodów Europy, wybrani przedstawiciele milionów wypędzonych ze stron rodzinnych, po głębokim namyśle i w zgodzie ze swoim sumieniem, postanowili przed narodem niemieckim i opinią światową złożyć uroczystą deklarację, określającą obowiązki i prawa, jakie niemieccy wypędzeni ze stron rodzinnych uznają za swoją zasadę podstawową oraz za nieodzowny warunek powstania wolnej i zjednoczonej Europy." W tej preambule zwraca na początek uwagę przywołanie Boga, co najwyraźniej zostało przejęte z preambuły Ustawy Zasadniczej Republiki Federalnej. Można to uznać za świadomą aluzję $\mathrm{w}$ sensie pośredniego wyznawania konstytucyjnej hierarchii wartości. Przemawia za tym także przywoływanie celu, jakim jest zjednoczona Europa, pojawiające się także w preambule konstytucji oraz wyraźne określenie Karty jako „konstytucji” wypędzonych. Afirmujące podkreślenie chrześcijańskiego, zachodnioeuropejskiego kręgu kulturowego, chętnie cytowane przez krytyków Karty jako dowód na zręczny obskurantyzm czy obciążone złą sławą tradycje duchowe, które tu jakoby pozostają w mocy ${ }^{65}$, ma swój odpowiednik w rządowej deklaracji Konrada Adenauera z 20 września 1949 roku, w której pierwszy kanclerz Niemieckiej Republiki Federalnej opowiedział się dobitnie za „duchem chrześcijańskiej, zachodnioeuropejskiej kultury” jako fundamentem jego polityki ${ }^{66}$. Godna uwagi jest widoczna w preambule autopercepcja organizacji wypędzonych jako jedynego, rzekomo w drodze plebiscytu legitymizowanego przedstawiciela ich klienteli - roszczenie daleko wybiegające poza ramy tradycyjnego stowarzyszenia obywatelskiego. Stowarzyszenia wypędzonych postrzegały się zdecydowanie nie jako klasyczne grupy nacisku, reprezentujące partykularne interesy swoich członków, lecz raczej jako rodzaj narodowej awangardy, reprezentującej interesy całego narodu ${ }^{67}$. Ważnym sygnałem dla "tubylców”

\footnotetext{
${ }^{65}$ Por. np. R. Giordano: op. cit., s. 274.

${ }^{66}$ Por. K. von Beyme, Die großen Regierungserklärungen der deutschen Bundeskanzler von Adenauer bis Schmidt. Eingeleitet und kommentier, München-Wien 1979, s. 53-73, tutaj s. 73.

${ }^{67}$ Por. M. Stickler: »Ostdeutsch heißt Gesamtdeutsch«..., s. 99-136.
} 
był fakt, że w Karcie była mowa o prawach i obowiązkach wypędzonych, co podkreślało wolę konstruktywnej współpracy w nowej ojczyźnie.

1. My, wypędzeni ze stron ojczystych, rezygnujemy z zemsty i odwetu. Postanowienie to traktujemy poważnie i jest ono dla nas święte, bowiem wyptywa ono z pamięci o nieskończonych cierpieniach, jakie przypadty w udziale ludzkości szczególnie w ostatnim dziesięcioleciu.

Temu fragmentowi krytycy Karty chętnie zarzucaja, że nie ma w nim mowy o niemieckiej odpowiedzialności za II wojnę światową ${ }^{68}$. Ta ocena jest słuszna, co najwyżej między wierszami można znaleźć myśl o niemieckiej winie ${ }^{69}$. Pomimo to nie należy nie doceniać uczynionego w Stuttgarcie gestu, gdyż pochodził on przecież z kręgu ofiar ${ }^{70}$, których głęboko traumatyczne doświadczenia miały miejsce zaledwie przed kilku laty. Postulat zrezygnowania z zemsty i odwetu pojawił się po raz pierwszy wyraźnie w 1948 roku w kręgu Wspólnoty Ackermanna (Ackermanngemeinde) ${ }^{71}$. Ważne $\mathrm{w}$ tym kontekście jest uświadomienie sobie, że zarówno tego rodzaju sformułowania, jak też kryjące się za nimi postrzeganie siebie jako niewinnych ofiar wcale nie były właściwe tylko wypędzonym. Raczej pasują one znakomicie do samoświado-

${ }^{68}$ Por. J.M. Piskorski: op. cit., s. 36; W. Benz: Fünfzig Jahre nach der Vertreibung. Einleitende Bemerkungen, w: W. Benz (red.): Die Vertreibung der Deutschen aus dem Osten. Ursache, Ereignisse, Folgen, Frankfurt am Main ${ }^{2} 1995$, s. 8-15, tutaj s. 11 i n.; K. Erik Franzen: In der neuen Mitte der Erinnerung. Anmerkungen zur Funktion des Opferkurses, "Zeitschrift für Geschichtwissenschaft”, 2003, z. 1, s. 49-53, a także - wysoce polemicznie - M. Brumlik: op. cit., s. 91 i nn. Brak wyraźnego przyznania się do winy zarzucał już w 1965 roku pochodzący z Kraju Sudeckiego sufragan Adolf Kindermann, twórca kościelnych instytucji w Königstein; por. S. Voßkamp: Katholische Kirche und Vertriebene in Westdeutschland. Integration, Identität und ostpolitischer Diskurs 1945-1972, Stuttgart 2007, s. 265 i n.

${ }_{69} \mathrm{Na}$ temat obrachunku wypędzonych z kwestią niemieckiej winy por. obszerne opracowanie: M. Stickler: »Ostdeutsch heißt Gesamtdeutsch«..., s. 100 i nn.

${ }^{70} \mathrm{Na}$ temat tej niekiedy kontrowersyjnie dyskutowanej kwestii por. przede wszystkim trafny artykuł M. Schwartza: Dürfen Vertriebene Opfer sein? Zeitgeschichtliche Überlegungen zu einem Problem deutscher und europäischer Identität, "Deutschland-Archiv“ 2005, z. 38, s. 494-505.

${ }^{71}$ Por. K. Erik Franzen: Der vierte Stamm Bayerns. Die Schirmherrschaft über die Sudetendeutschen 1954-1974, München 2009, s. 117. Stawiane przez krytyków Karty retoryczne pytanie, czy wypędzeni w ogóle mają prawo do zemsty i odwetu, z którego mogliby rezygnować (por. np. E. Hahn, H. Henning Hahn (red.): op. cit., s. 446 i n.), jest niczym więcej niż polemiczną rozrywką umysłową, zważywszy na fakt, iż choćby pobieżne spojrzenie na historię uchodźstwa i wypędzeń w XX wieku uczy, że zemsta i odwet ich ofiar wcale nie były wyjątkiem, a raczej regułą. 
mości całego powojennego społeczeństwa, tworzącego się w Republice Federalnej, a określającego się w obliczu „niemieckiej katastrofy“ - jak to zaraz po zakończeniu wojny nazwał wiekowy Friedrich Meinecke ${ }^{72}$ - przede wszystkim jako społeczeństwo ofiar. Genezę i treści dyskursu na temat ofiar zanalizował obszernie przed około 10 laty amerykański historyk Robert G. Moeller w ważnym studium ${ }^{73}$, pisząc: „Moja teza brzmi $[\ldots]$, że konfrontacja $\mathrm{z}$ dwiema historiami ofiar $-\mathrm{z}$ jednej strony z historią nazistowskich zbrodni i ich ofiar, z drugiej zaś z własną przeszłością w roli ofiar - oraz ich konfrontacja była ważnym czynnikiem, który umożliwił zachodnim Niemcom stworzyć po czasach narodowego socjalizmu prawowitą polityczną tożsamość. »Droga do Izraela« Niemiec Zachodnich i ich pojednanie z państwem, które stało się ojczyzną wielu prześladowanych przez Hitlera Żydów, utorowały ponadto drogę do akceptacji i przyłączenia do zdominowanego przez USA zachodniego sojuszu. Natomiast fakt, iż uwaga opinii publicznej skierowała się ku doświadczeniom wypędzonych i jeńców wojennych w Związku Sowieckim, stał się kamieniem milowym na drodze do wewnątrzniemieckiego paktu społecznego. Tworzyła go wspólnota cierpienia i współczucia Niemców, których łączyło wspólne zadanie ponoszenia kosztów wojny “74. W stworzeniu tej wspólnoty ofiar Moeller upatruje najważniejszy element swoistego zachodnioniemieckiego Nation Building. Według niego Niemcy zachodni próbowali „stworzyć kolektywną tożsamość, nieposługującą się nacjonalistycznym językiem. Tak więc jeden z najpotężniejszych integrujących mitów lat pięćdziesiątych wyróżnił Niemcy jako wspólnotę ofiar, definiującą się poprzez doświadczenie utraty i wypędzenia podczas II wojny światowej. Wypędzeni i jeńcy wojenni pozwolili zachodnim Niemcom całkiem legalnie wziąć udział w moralnej licytacji o to, kto najbardziej cierpiał podczas wojny. Skupiając się na doświadczeniach wypędzonych i przeżyciach jeńców 1946.

${ }^{72}$ F. Meinecke: Die deutsche Katastrophe. Betrachtungen und Erinnerungen, Wiesbaden

${ }^{73}$ R.G. Moeller: War Stories. The Search for a Usable Past in the Federal Republic of Germany, Berkeley 2001. Por. także idem: Deutsche Opfer, Opfer der Deutschen. Kriegsgefangene, Vertriebene, NS-Verfolgte: Opferausgleich als Identitätspolitik, w: K. Naumann (red.): Nachkrieg in Deutschland, Hamburg 2010, s. 29-58.

${ }^{74}$ R.G. Moeller: Deutsche Opfer..., s. 32. 
wojennych w Związku Sowieckim, zachodni Niemcy mogli rozmawiać o końcu »III Rzeszy« bez brania na siebie odpowiedzialności za jej początki. W tej skróconej wersji historii narodowego socjalizmu ostatecznie wszyscy Niemcy byli ofiarami wojny, którą co prawda rozpętał sam Hitler, ale na koniec wszyscy byli przegrani. Takie rozłożenie akcentów wpływało także na sposób przedstawiania narodowego socjalizmu. Zgodnie z nim sprawcami nazistowskich zbrodni była garstka fanatycznych wyznawców, którzy jednak w żadnym wypadku nie reprezentowali całego niemieckiego narodu. W świetle retoryki z lat pięćdziesiątych Żydzi i inni ponieśli co prawda ogromne straty, ale przecież także i Niemcy. [...] Niemieckie ofiary były członkami zachodnioniemieckiej imagined community. Natomiast ofiary Niemców nie należały do tej

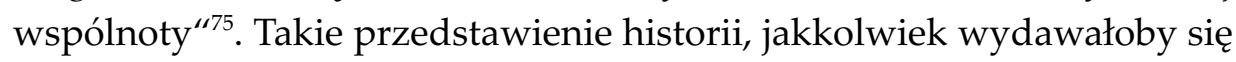
wątpliwe z dzisiejszej perspektywy, odniosło sukces, także akurat przy napiętnowaniu narodowego socjalizmu: „Obszerne publiczne omawianie ciężkiego położenia i praw różnych »poszkodowanych przez wojnę« pozwoliło wypędzonym i jeńcom wojennym odegrać wyjątkowo ważną rolę przy definiowaniu powojennego paktu społecznego, polegającego na potępieniu wszelkich przejawów autorytarnej władzy. Retoryka ofiar [...] implikowała w wyraźny sposób odejście od narodowego socjalizmu i wojny Hitlera, które miały wyrządzić krzywdę Niemcom. Elementem tego politycznego języka była wyraźnie sformułowana krytyka pod adresem komunistycznych reżimów. [...] Wszystkie większe partie polityczne mogły zaaprobować taki obrachunek z przeszłością, gdyż nie dotyczył on sfery partyjnych walk o własny profil. Określał on obszar, w którym wszyscy poza komunistami mogli się odnaleźć i spotkać" ${ }^{\prime 76}$.

Przemiana teorii ofiar rozpoczęła się w przypadku organizacji wypędzonych, a z pewnym opóźnieniem w całym społeczeństwie Republiki Federalnej, stopniowo od lat sześćdziesiątych, szczególnie zaś od lat dziewięćdziesiątych, przy czym należy stwierdzić, że relikty dawnego sposobu myślenia działają do dziśs ${ }^{77}$. W dużym stopniu nieznany

${ }^{75}$ Ibidem, s. 33 i n.

${ }^{76}$ Ibidem, s. 55 i n. oraz s. 57.

77 Wspomnieć tu należy o sporach wokół wypowiedzi polityków Arnolda Tölga i Hartmuta Sängera (por. S.F. Kellerhoff: Zentralrat stoppt Mitarbeit, „Vertriebenen-Stif- 
jest fakt, iż w ścisłym związku z Karta, mianowicie dzień przed jej podpisaniem, czeskie zgromadzenie narodowe (emigracyjna organizacja czeskich opozycjonistów, mieszkających w Londynie) oraz „Monachijska wspólnota ochrony interesów Niemców sudeckich“ (Münchener Arbeitsgemeinschaft zur Wahrung sudetendeutscher Interessen, dziś: Sudetendeutscher Rat), podpisały w tzw. Układzie z Wiesbaden dokument pojednania, odrzucający kolektywną winę oraz - podobnie jak Karta zamiar zemsty po obu stronach oraz żądający ukarania najważniejszych odpowiedzialnych osób ${ }^{78}$. Nie należy więc chyba wątpić w zasadniczo istniejąca gotowość organizacji wypędzonych do porozumienia się z narodami Europy Wschodniej, jednak jej podstawa była nieco chwiejna, gdyż wychodziła w dwóch decydujących punktach z fałszywych przesłanek. Po pierwsze, zakładała, że stanowisko organizacji wypędzonych w kwestii prawa ojczystego ${ }^{79}$, czyli żądanie naprawienia doznanej szkody poprzez przyznanie prawa do powrotu i prawa do samostanowienia, jest bez zastrzeżeń uznawane przez drugą stronę. Zdaniem organizacji wypędzonych powrót i rewizja granic były jakby wstępnym warunkiem porozumienia, przy czym sami mieli z początku kłopoty z uznaniem prawa ojczystego Polaków, żyjących od 1945 roku na dawnych niemieckich terenach wschodnich. Dopiero w latach sześćdziesiątych zaczęli zmieniać swą postawę ${ }^{80}$. Po drugie, stanowisko stowarzyszeń wypędzonych w dużym stopniu karmiło się iluzją że istnieje na fundamencie

tung“, 6 września 2010, online <http://www.welt.de/politik/deutschland/article9441982/ Zentralrat-stoppt-Mitarbeit-in-Vertriebenen-Stiftung.html> [17.10.2010], oraz Dafür gibt es gar keinen Anlass, dass ich auf diese Aufgabe verzichte. Tölg verteidigt seinen Sitz im Vertriebenen-Stiftungsrat Arnold Tölg im Gespräch mit Dirk-Oliver Heckmann, „Deutschlandradio Kultur", 3 sierpnia 2010, online <http://www.dradio.de/dlf/sendungen/interview _ dlf/1239563/> [17.10.2010]). Takie zdarzenia można zapewne ocenić jako dowód na to, że część BdV życzy sobie nadal tradycyjnych wzorców interpretacji, których korzenie sięgają dyskursów na temat polityki pamięci, prowadzonych w latach pięćdziesiątych.

${ }_{78}$ Por. F.P. Habel (red.): Dokumente zur Sudetenfrage. Unerledigte Geschichte, München ${ }^{5} 2003$, s. 724 i n.

${ }^{79}$ Por. M. Stickler: »Ostdeutsch heißt Gesamtdeutsch«..., s. 362-364.

${ }^{80}$ Por. ibidem, s. 364-369 oraz rezolucję I Kongresu wschodnioniemieckich przedstawicielstw krajowych z 22 marca 1964 roku, w której stwierdzono, że „przywracanie złamanego prawa wyklucza niehumanitarne postępowanie“ oraz że uznano prawo ludności, osiedlonej po 1945 roku, do pozostania (por. „Deutscher Ostdienst“ 1964, nr 12-13, s. 13). Por. także pismo przewodniczącego Kongresu Philippa von Bismarcka do Urzędu Kanclerskiego z 6 marca 1964, Bundesarchiv Koblenz, B 136-6787. 
antykomunizmu daleko idąca zbieżność interesów pomiędzy Polakami i niemieckimi wypędzonymi. Organizacje wypędzonych nie chciały dostrzec, że sprawa granic uważana była w Europie Wschodniej za sprawę egzystencjalną i że w tym punkcie istniała zbieżność interesów pomiędzy rządzącymi partiami komunistycznymi i rządzonymi. Trudne były także w dłuższej perspektywie kontakty z organizacjami emigrantów, $\mathrm{w}$ większości dystansującymi się wobec stowarzyszeń wypędzonych ${ }^{81}$.

2. Ze wszystkich sit wspierać będziemy wszelkie inicjatywy zmierzajace do powstania zjednoczonej Europy, w której poszczególne narody żyć będa mogły bez trwogi i przymusu.

Tutaj wypędzeni opowiedzieli się jednoznacznie za wspomnianym wyżej antytotalitarnym konsensusem we wczesnej Republice Federalnej, cechującym się w okresie zimnej wojny przede wszystkim antykomunizmem. Przyczynił się on zdecydowanie do integracji tradycyjnej niemieckiej prawicy z młodą demokracją ${ }^{82}$. Tak długo jak podstawowy konsensus powojennego społeczeństwa w Niemczech Zachodnich oraz zasady polityki, opartej na powstrzymywaniu sowieckiej ekspansji i aktywnie dążącej do zjednoczenia Niemiec z rewizją granicy na Odrze i Nysie jako bliskim celem, pozostawały w mocy, tak długo zaangażowanie organizacji wypędzonych $\mathrm{w}$ prawo do powrotu, samostanowienia i rewizji granic miało integrujące działanie. Dzięki temu programowi stowarzyszenia plasowały się w samym centrum społeczeństwa i były zdolne przyłączyć się do wszystkich partii demokratycznego spektrum. Zmieniło się to dopiero od końca lat pięćdziesiątych, kiedy zasadniczy konsensus stawał się pod wpływem zmian w polityce wewnętrznej i zagranicznej coraz bardziej defensywny.

3. Ciężka i wytrwała praca będziemy uczestniczyć w odbudowie Niemiec i Europy.

Także w tym fragmencie podkreślono ponownie bezwarunkową wolę aktywnego współdziałania w nowej ojczyźnie. Było to potrzebne głównie z tego powodu, żeby nie dopuścić lub osłabić zawiść, jaka mogła się pojawić pomiędzy wypędzonymi i miejscową ludnością w związku z debatami na temat wyrównania szkód. Jednocześnie wypędzeni

\footnotetext{
${ }^{81}$ Por. obszernie u M. Sticklera: »Ostdeutsch heißt Gesamtdeutsch«..., s. 351-354.

${ }^{82}$ Por. ibidem, s. 360 i n.
} 
ponownie demonstracyjnie opowiedzieli się za jednością Europy, rozumianą jako wspólnota antykomunistycznych demokracji zachodnich.

Utraciliśmy nasze strony rodzinne. Ludzie, którzy nie posiadaja stron rodzinnych sa na tym świecie ludźmi bezdomnymi. Bóg wyznaczył ludziom ich strony rodzinne. Wyrwanie człowieka pod przymusem z jego stron rodzinnych, oznacza jego duchowe unicestwienie. Los ten i zwiazane z nim cierpienia przypadty nam $w$ udziale. Stąd czujemy się powotani żadać, aby prawo do stron rodzinnych jako jedno $z$ danych od Boga, podstawowych praw ludzkości zostało uznane i urzeczywistnione. Dopóty, dopóki prawo to nie zostanie w stosunku do nas urzeczywistnione, nie zamierzamy stać na uboczu skazani na bezczynność, lecz chcemy dziatać $i$ tworzyć w ramach nowych, udoskonalonych form petnych zrozumienia i braterskiego wspótżycia ze wszystkimi członkami naszego Narodu.

Tutaj stowarzyszenia wypędzonych po raz pierwszy sformułowały tzw. prawo do ojczyzny ${ }^{83}$, uzasadniając je wartościami chrześcijańskimi bądź prawem naturalnym ${ }^{84}$. Żądanie urzeczywistnienia "prawa do ojczyzny" odgrywało podstawową rolę w realizowanej polityce organizacji wypędzonych. Wyraźnie widać tu jednak janusowe oblicze pojęcia ojczyzny w ujęciu wypędzonych. $Z$ jednej strony mamy do czynienia z mityczno-uduchowioną, religijną względnie parareligijną konotacja, odwołującą się do osobistych, indywidualnych wspomnień z ojczyzny, jako że przywołującą konkretną ojczyznę pokolenia, które zostało z niej wypędzone i którego doświadczenia starano się przekazać. Z drugiej strony było to raczej abstrakcyjne pojęcie ojczyzny, niezwiązane z konkretnymi doświadczeniami, przenoszące je na płaszczyznę symbolu i stylizujące wypędzenie na alegoryczne wydarzenie, mające być nieustającym ostrzeżeniem, zobowiązującym także potomków wypędzonych i miejscową ludność do naprawienia doznanych szkód. Konkretnie oznaczało to, jeśli nawet nie napisano tego w Karcie, iż z prawa do ojczyzny względnie do powrotu do niej wynika ostateczny cel - rewizja „poczdamskich granic” Niemiec. Linus Kather wyjaśnił to w swoim przemówieniu z 5 sierpnia 1950 roku w Bad Cannstadt w nieco zawoalowany, jednak zrozumiały sposób: „Opowiadają się one [postulaty i za-

${ }^{83}$ Por. obszernie ibidem, s. 357-369.

${ }^{84}$ Uzasadnione prawem naturalnym i historycznym aspiracje do ojczyzny, podobnie jak rezygnacja z zemsty i odwetu, sformułowała już w 1948 roku Wspólnota Ackermanna; por. K. Erik Franzen: Der vierte Stamm Bayerns..., s. 117. 
sady Karty] za wiecznym i niezbywalnym prawem do naszej ojczyzny i wyrażają wolę, aby nigdy i w żadnym wypadku nie rezygnować z tego prawa. [...] Podnoszą roszczenia wypędzonych do niezbędnej przestrzeni życiowej (Lebensraum) i pełnego równouprawnienia w narodzie niemieckim" ${ }^{\prime 85}$. To żądanie wypędzonych było wówczas zgodne z zasadniczym konsensusem w młodej Republice Federalnej. Na przykład podczas wyborów do Bundestagu w 1949 roku SPD prowadziła kampanię pod hasłem "Naprzód ku wolnym Niemcom“, posługując się plakatem, pokazującym niemieckie granice z 1914 roku(!) ${ }^{86}$. Propagowanie prawa do ojczyzny miało na koniec służyć próbie ubrania rewizjonistycznego celu odzyskania dla Niemiec terenów na Wschodzie w humanistyczno-idealistyczne szaty jako wielkiego zadania ludzkości ${ }^{87}$. Było to potrzebne z dwóch powodów. Po pierwsze, żeby móc uporać się z zarzutem partykularnych interesów bądź wstecznego nacjonalizmu, po drugie - aby poradzić sobie z problemem zmiany pokoleń lub udanej integracji imigrantów, co groziło rozwiązaniem problemu wypędzenia w jakby naturalny, biologiczny sposób. Używanie przez wypędzonych pojęcia ojczyzny budzi wątpliwości z uwagi na fakt, iż w efekcie postulowano rzekomo istniejącą $\mathrm{w}$ dawnych ojczyznach, idealną jedność pomiędzy ludźmi, kulturą i przyrodą którą należało przywrócić przez powrót, co oznaczało także dążenie do przywrócenia pełnego status quo ante ${ }^{88}$. Punktem odniesienia dla dążeń wyznawców „Heimatpolitik” był niezmiennie stan sprzed wojny, nie zaś współczesny, dlatego też z czasem pojęcie ojczyzny stało się nieco sztuczne. Definicja prawa do ojczyzny jako prawa grupowego miała podstawowe znaczenie głównie $z$ tego powodu, iż na tej podstawie organizacje wypędzonych formułowały swe rzekome prawo do wetowania „kapitulanckich tendencji”. Takie roszczenia były dla Republiki Federalnej oczywiście nie do zaakceptowania, ich uznanie oznaczałoby przecież, iż wypędzeni tworzą mniejszość ze szczególnymi uprawnieniami.

\footnotetext{
${ }^{85}$ L. Kather: op. cit., t. 1, s. 170.

${ }^{86}$ Por. http://www.spd-tannenhof.eu/41379/41388.html [8.12.2010].

${ }^{87}$ Por. obszernie w I. Zeiträg: Die Selbstdarstellung der deutschen Vertriebenenverbände als Reflex ihrer gesellschaftlichen Situation, Hamburg 1970, s. 50 i nn.

${ }^{88}$ Por. H.J. Brües: Artikulation und Repräsentation politischer Verbandsinteressen, dargestellt am Beispiel der Vertriebenenorganisationen, Köln 1972, s. 48.
} 
Dlatego też domagamy się i żadamy, tak dziś jak i wczoraj:

1. Równych praw obywatelskich, nie tylko w obliczu prawa, lecz również w rzeczywistości dnia codziennego.

2. Sprawiedliwego i sensownego podziału ciężarów ostatniej wojny na cały naród niemiecki oraz uczciwego przestrzegania tej zasady.

3. Szerokiego wykorzystania wszystkich grup zawodowych spośród wypędzonych ze stron rodzinnych w życiu niemieckiego narodu.

4. Czynnego właczenia niemieckich wypedzonych ze stron rodzinnych w odbudowe Europy.

Chodzi tu o konkretne wewnątrzpolityczne żądania wobec Republiki Federalnej i jej krajów związkowych, które na koniec miały znaleźć ujście w ustawach o wyrównaniu szkód ${ }^{89}$. Nie da się przecenić wkładu wypędzonych $w$ odbudowę Niemiec. Zdecydowanie przyczynili się do tzw. cudu gospodarczego, gdyż byli skorzy i zdolni do integrowania się, poza tym w większości dobrze wykształceni i chętni do pracy. Na początku stanowili niewyczerpaną rezerwę taniej siły roboczej, dźwigającej na swych barkach w dużej części ciężar odbudowy. Tak zwane wyrównanie szkód należało do największych społeczno-politycznych wyzwań wczesnej Republiki Federalnej i było najbardziej kontrowersyjnym, w końcowym efekcie, jednak też jej najbardziej udanym ustawodawczym przedsięwzięciem. Kompromis w tej sprawie, w dużym stopniu decydującej o wewnętrznej stabilności Republiki Federalnej, osiągnięto po długich potyczkach w Ustawie o wyrównaniu szkód z 14 sierpnia 1952 roku. Największym problemem było znalezienie kompromisu pomiędzy uzasadnionym prawem wypędzonych do odpowiedniego odszkodowania a uniknięciem szeroko zakrojonego podziału majątku, który mógłby zagrozić polityce wzrostu, opartej na gospodarce rynkowej. Potrzebne

${ }^{89}$ Na temat wyrównania szkód w Republice Federalnej por. głównie: P. Erker: Rechnung für Hitlers Krieg. Aspekte und Probleme des Lastenausgleichs, Heidelberg 2004; R. Fritz: Der Einfluss der Parteien und Geschädigtenverbände auf die Schadensfeststellung im Lastenausgleich, Berlin 1964; H. Neuhoff: Der Lastenausgleich aus der Sicht der Vertriebenen, w: H.J. von Merkatz (red.): Aus Trümmern wurden Fundamente. Vertriebene/Flüchtlinge/Aussiedler. Drei Jahrzehnte Integration, Düsseldorf 1979, s. 129-149; A. Sywottek: Der Entscheidungsprozess beim Lastenausgleich 1945-1952, St. Katharinen 1998; R. Wenzel: Die große Verschiebung? Das Ringen um den Lastenausgleich im Nachkriegsdeutschland von den ersten Vorarbeiten bis zur Verabschiedung des Gesetzes 1952, Stuttgart 2008; L. Wiegand: Der Lastenausgleich in der Bundesrepublik Deutschland 1949-1985, Frankfurt am Main 1992 (jednocześnie Heidelberg 1991). 
sumy zebrano w końcu dzięki opłatom wyrównawczym od posiadających, w sektorze publicznym, dzięki kredytom i wpływom z pożyczek. Godne uwagi jest w Karcie ponowne, demonstracyjne podkreślenie zadania „odbudowy Europy”, co znów rozszerza pole argumentacji poza państwo narodowe oraz sygnalizuje gotowość do pojednania.

Narody świata winny poczuwać się do wspótodpowiedzialności za wypędzonych ze stron rodzinnych, jako tych, których niedola tego czasu dotknęta najbardziej.

Narody te winny postępować zgodnie z ich chrześcijańskim obowiazkiem i w zgodzie z ich sumieniem.

Narody te musza sobie uświadomić, iż los niemieckich wypędzonych ze stron rodzinnych, podobnie jak los wszystkich uchodźców, jest problemem globalnym, którego rozwiazanie obok najwyższej moralnej odpowiedzialności i poczucia obowiazku, wymaga również ogromnego wysiłku.

Wzywamy narody $i$ wszystkich ludzi dobrej woli, aby przyłożyli rękę do dzieła, które pozwoli nam wszystkim odnaleźć droge prowadząca z winy, nieszczęścia, biedy i cierpienia - ku lepszej przyszłości.

Tutaj ponownie podkreślono samoocenę wypędzonych jako niewinne ofiary, przy czym z dzisiejszej perspektywy sformułowanie, iż wypędzeni mieliby być tymi, których niedola tego czasu dotknęła najbardziej, musi oczywiście budzić zdumienie w obliczu rozmiarów zbrodni narodowego socjalizmu. Tę wręcz autystyczną ocenę można wyjaśnić chyba jedynie opisanym powyżej dyskursem na temat ofiar, należącym do konsensusu wczesnej Republiki Federalnej. Jednocześnie należy wspomnieć, że wypędzeni konkurowali w Niemczech Zachodnich z innymi niemieckimi ofiarami wojennymi (np. jeńcami wojennymi, poszkodowanymi w wyniku bombardowań, wdowami po żołnierzach i sierotami, niemieckimi ofiarami nazistowskiego reżimu), wśród których chcieli się wyróżnić. Tego typu wypowiedzi przepowiadały gwałtowne spory o wyrównanie szkód, które zapoczątkował Kather 6 sierpnia 1950 roku podczas wiecu w Stuttgarcie, gdzie ostro zaatakował federalnego ministra finansów Fritza Schäffera (CSU), co obecny przy tym wicekanclerz Blücher uznał za wielce niestosowne ${ }^{90}$. Na dodatek dzień wcześniej Kather otwarcie zagroził radykalizacją stanowiska wy-

\footnotetext{
${ }^{90}$ L. Kather: op. cit., t. 1, s. 171.
} 
pędzonych, jeśli nie spełni się ich uzasadnionych żądań: „Oba reprezentowane przez stowarzyszenia wypędzonych kierunki nie są jeszcze radykalne, z umiarkowaniem występują w sprawie słusznych żądań. Jeśli używają zdecydowanych sformułowań i coraz ściślej współdziałają to nie ma to nic wspólnego $\mathrm{z}$ radykalizacją. Jeśli jednak nasz głos nadal nie będzie słyszany, to wypędzeni dadzą posłuch tym, którzy opowiadają się za stuprocentowymi rozwiązaniami, nie bacząc na to, czy mają one realne podstawy, czy też nie. Najsilniejszą bronią w walce o realizację naszych słusznych interesów, jednocześnie najmocniejszą gwarancją wspierania stabilnego rozwoju politycznego jest zwarta, ponadpartyjna organizacja wypędzonych" ${ }^{\prime 91}$.

Godne uwagi w cytowanym powyżej fragmencie Karty jest - niewątpliwie trafne - spojrzenie na los niemieckich wypędzonych jako część globalnego problemu. To sformułowanie niekoniecznie należy interpretować jako próbę pozbycia się niemieckiej winy względnie apologetycznego wyrwania ucieczki i wypędzenia z politycznego kontekstu nazistowskich Niemiec. Chodzi tu raczej o pierwszy krok na długiej i bolesnej drodze do nowej interpretacji losu wypędzonych, która w efekcie pozwoliła Niemcom odejść od postrzegania siebie jako pępka świata i skupiania się na swojej roli ofiar. Krok ten otworzył drzwi do prawdziwego pojednania ze wschodnimi sąsiadami Niemiec. Dobrym przykładem konstruktywnego stanowiska organizacji wypędzonych np. wobec Polski, pochodzącego już z lat pięćdziesiątych, jest memoriał o wspieraniu kontaktów kulturalnych z Polską (Denkschrift zur Förderung der kulturellen Beziehungen mit Polen) z 16 stycznia 1959 roku $^{92}$. Przy jego ocenie należy pamiętać, że Związek Wypędzonych stanowczo odrzucał nawiązanie stosunków dyplomatycznych oraz pogłębianie kontaktów gospodarczych z Polską Rzeczpospolitą Ludową ${ }^{93}$. Tego rodzaju staraniom, które z punktu widzenia Związku Wypędzonych

${ }^{91}$ Ibidem, s. 170 i n. Ostatnie zdanie należy rozumieć jako cios w kierunku VOL, zarazem też jako wezwanie wobec partii politycznych względnie rządu federalnego, aby jego, Kathera, uznać za właściwego reprezentanta wypędzonych, który jako jedyny jest w stanie skupić ich potencjał wyborczy - znakomity przykład na przecenianie własnych sił względnie arogancję Kathera w sporach politycznych.

${ }_{22}$ Politisches Archiv des Auswärtigen Amtes Berlin, B 12, t. 289 oraz Bundesarchiv Koblenz, B 150/4331, także „Vertriebenenkorrespondenz" 1959, z. 2, s. 11.

${ }^{93}$ Por. obszernie u M. Sticklera: »Ostdeutsch heißt Gesamtdeutsch«..., s. 374 i nn. 
niepotrzebnie dowartościowałyby komunistyczny reżim w Warszawie i udaremniały politykę separacji, przeciwstawiano postulat umacniania kontaktów poniżej szczebla państwowego. W memoriale czytamy m.in.: „BdV pragnie zgodnie z duchem Karty wypędzonych z stron rodzinnych pokonywać przeciwieństwa pomiędzy niemieckim i polskim narodem. Daleki od nienawiści i uprzedzeń uznaje każdą obcą osobowość narodową i jej prawo do życia oraz żąda prawa do samostanowienia tak dla niemieckiego, jak i polskiego narodu. Pragnąc służyć niezbędnemu porozumieniu obu narodów, pokojowi w Europie oraz stworzeniu atmosfery, ułatwiającej rozwiązywanie także politycznych kwestii, BdV wspiera rozszerzenie i ustalenie wytycznych dla kontaktów kulturalnych pomiędzy obu narodami i poszczególnymi osobami oraz przedstawia w tym celu następujące konkretne propozycje". Wymieniono następnie przede wszystkim utrzymywanie i pogłębianie wymiany naukowej i kulturalnej, spotkania młodzieży i kontakty między sportowcami, ułatwienia w ruchu turystycznym oraz wspieranie polskiej kultury oraz „wschodnioeuropejskiej“ wiedzy w Niemczech, np. poprzez stworzenie polskiego internatu, wspieranie ludzi kultury w Polsce i nauczanie języka polskiego. Otwarta pozostawała kwestia, jak można by realizować taki program w obliczu totalitarnych aspiracji rządzącej Polskiej Zjednoczonej Partii Robotniczej bez jej udziału lub wręcz w opozycji do niej, ale też stwierdzono w memoriale, iż jak najbardziej dostrzega się ogromne trudności i nie oczekuje się szybkich sukcesów.

\section{Wnioski}

Niniejszy artykuł wykazuje zapewne wyraźnie, iż Karta niemieckich wypędzonych ze stron ojczystych pomimo niektórych zawartych $\mathrm{w}$ niej sformułowań, które dzisiaj brzmią dziwnie, dają się jednak wytłumaczyć historycznym kontekstem, jest godnym uwagi świadectwem historycznym, dokumentującym wolę integracji ze strony wypędzonych i ich gotowość do prawdziwego pojednania ze wschodnimi sąsiadami Niemiec. Słuszne jest co prawda stwierdzenie, że droga organizacji wypędzonych od pierwotnego dążenia do powrotu i rewizji granic była długa, trudna i bolesna, patrząc z dzisiejszej perspektywy także pełna 
kroków wstecz i błędnych decyzji. Jednak uprawnione będzie twierdzenie, iż fakt, że Związek Wypędzonych odgrywa dzisiaj - co prawda w porównaniu ze wczesną Republiką Bońską mniejszą - nadal jednak istotną społeczno-polityczną rolę, bierze się z wczesnego uzgodnienia przez organizacje wypędzonych programu pojednania wewnątrz Niemiec i poza ich granicami, jak to wyrażono w Karcie ze Stuttgartu. W tym sensie uprawnione byłoby powtórzenie za Jürgenem Danyelem i Christopherem Kleßmannem ${ }^{94}$, że Kartę należy postrzegać jako ważne wydarzenie, należące podobnie jak Memoriał z Tybingi, Memoriał Niemieckiego Kościoła Ewangelickiego, wymiana listów pomiędzy polskimi i niemieckimi biskupami oraz Memorandum z Bensbergu z lat sześćdziesiątych XX wieku do pojednawczych inicjatyw pomiędzy Niemcami i ich wschodnimi sąsiadami.

Przełożyła Marta Koszutska

\begin{abstract}
"We, the expellees" [from our native land], "renounce all thought of revenge and retaliation" - The Charter of Stuttgart, of 5-6 August 1950, as a historical document
\end{abstract}

German politicians, including those performing the office of Chancellor of the Federal Republic of Germany, have highly appreciated and continue to appreciate the Charter of the German Expellees. While the Charter is of crucial importance for the Federation of Expellees, there are, nevertheless, no scholarly analyses of how it came into being. The author describes how the German expellee organisations were formed in the first years after the war, how the Charter of the German Expellees itself was written and adopted and what role it performed. It combined the right to a native land with the renouncement of vengeance and revenge and also had the unity of Europe as its objective. It constituted part of the FRG society's self-perception as a community of victims. At the same time, it was a declaration of reconciliation, which made it possible for the Federation of Expellees to maintain the strong, political and social position that it continues to hold today. In the chain of initiatives aimed at reconciliation between Germany and its eastern neighbours, the Charter was an important link.

${ }^{94}$ J. Danyel, Ch. Kleßmann: Unterwegs wie die Flüchtlinge und Vertriebenen. Zur Debatte über ein europäisches Zentrum gegen Vertreibungen, "Zeitschrift für Geschichtwisschenschaft" 2003, z. 1, s. 31-35, tutaj s. 32. 